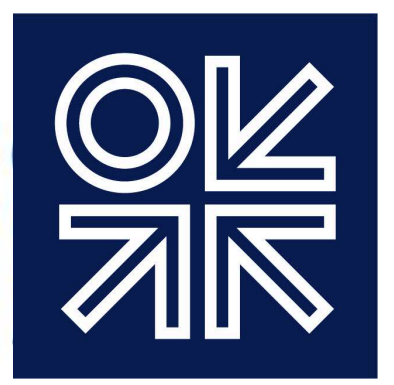

THE OXFORD INSTITUTE FOR ENERGY STUDIES

\title{
Utilization of Scenarios in European Electricity Policy:
}

\section{The Ten-Year Network Development Plan}



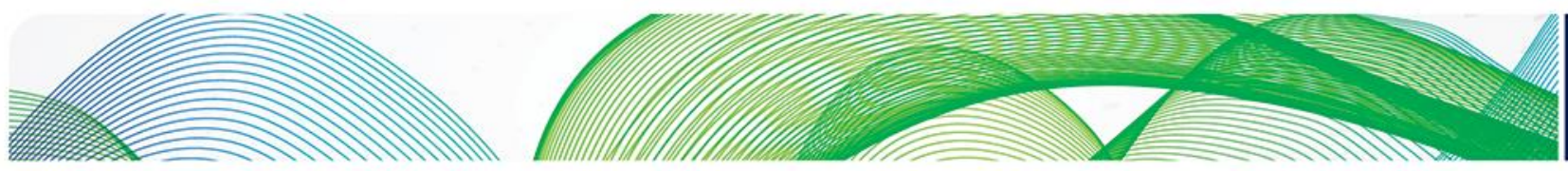

\section{잊조}

The contents of this paper are the author's sole responsibility. They do not necessarily represent the views of the Oxford Institute for Energy Studies or any of its members.

\section{Copyright $\odot 2018$}

\section{Oxford Institute for Energy Studies}

(Registered Charity, No. 286084)

This publication may be reproduced in part for educational or non-profit purposes without special permission from the copyright holder, provided acknowledgment of the source is made. No use of this publication may be made for resale or for any other commercial purpose whatsoever without prior permission in writing from the Oxford Institute for Energy Studies.

ISBN 978-1-78467-125-9

DOI: https://doi.org/10.26889/9781784671259 

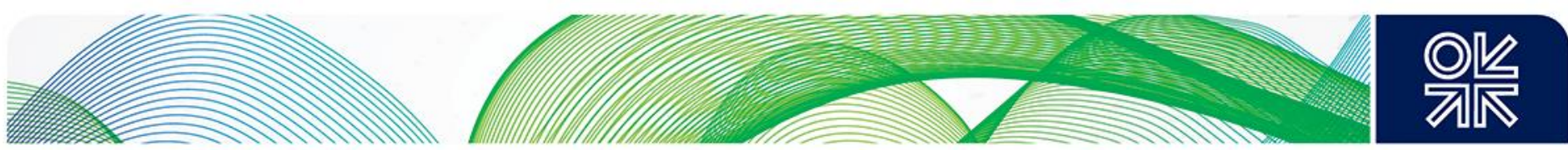

\section{Acknowledgements}

I would like to thank Malcolm Keay, David Buchan, and Rahmatallah Poudineh of Oxford Institute for Energy Studies for their helpful and detailed feedback on earlier versions of this paper. 

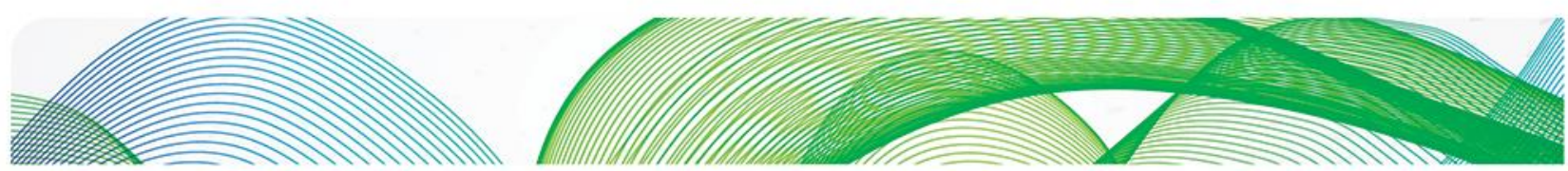
애잦

\section{Contents}

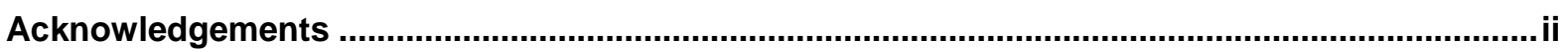

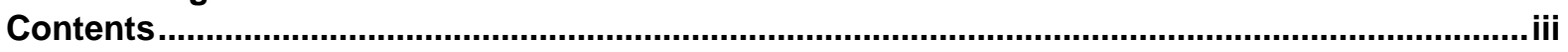

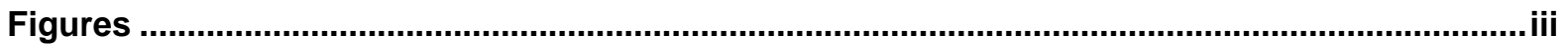

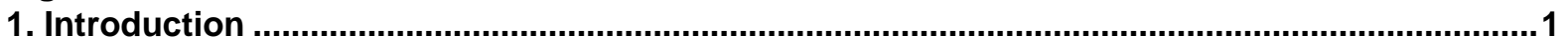

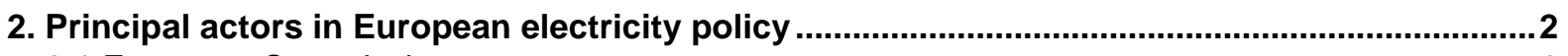

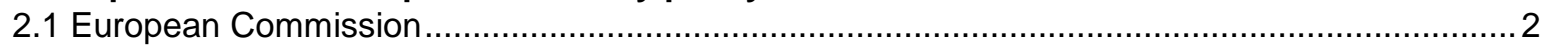

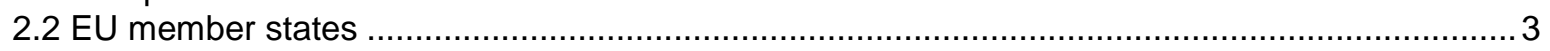

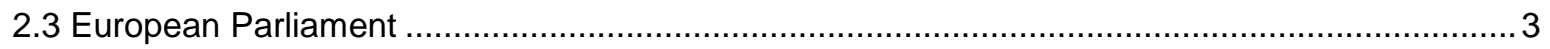

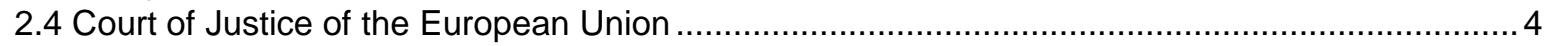

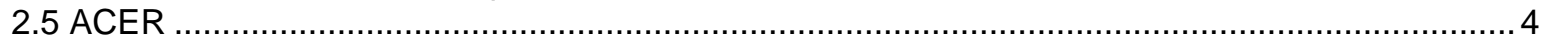

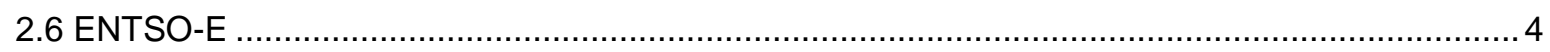

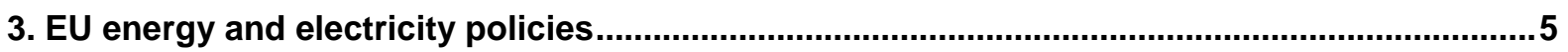

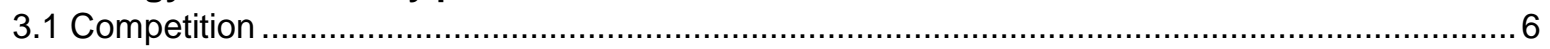

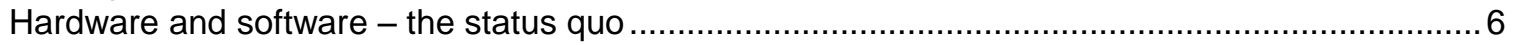

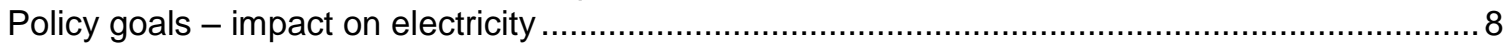

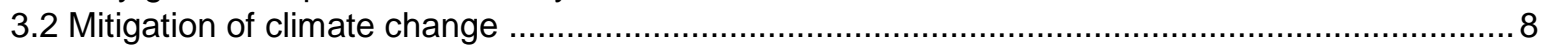

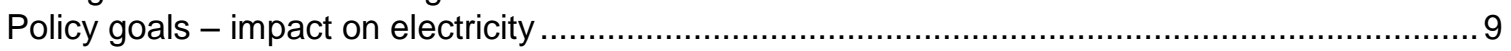

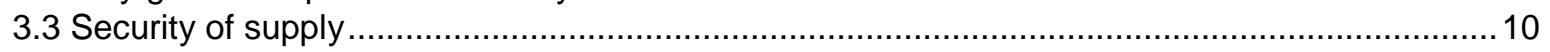

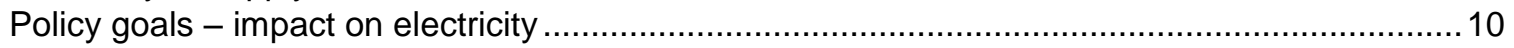

3.4 Summary of EU policies.............................................................................................. 11

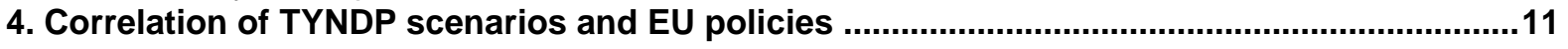

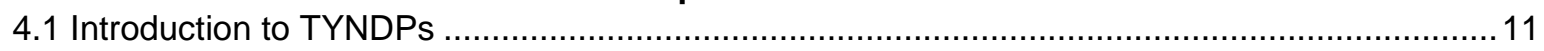

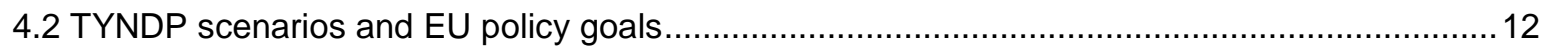

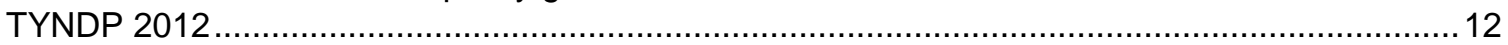

TYNDP 2014

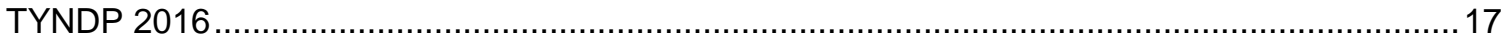

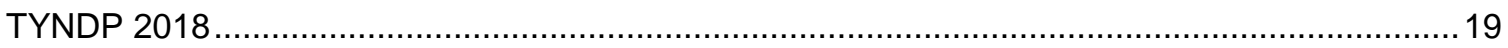

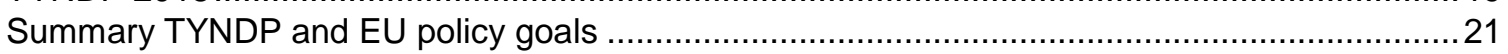

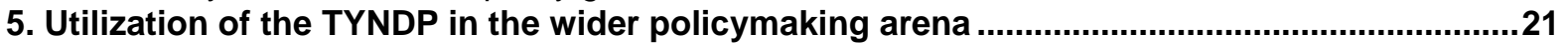

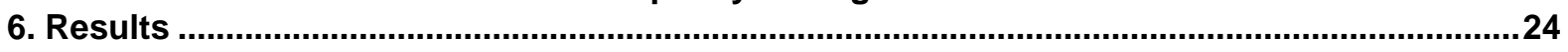

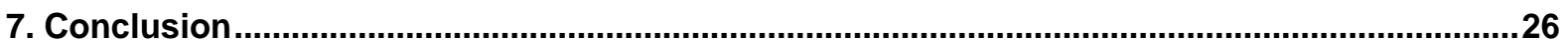

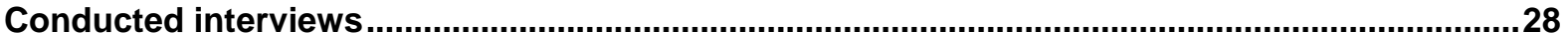

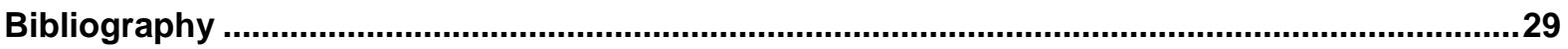

\section{Figures}

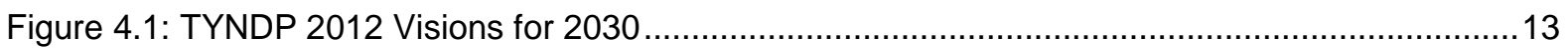

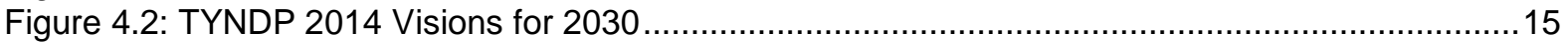

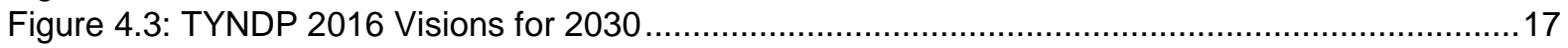

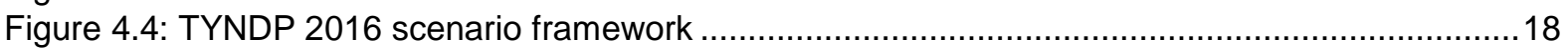

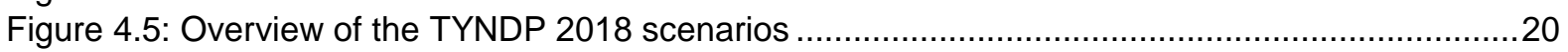

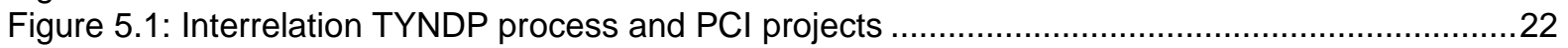



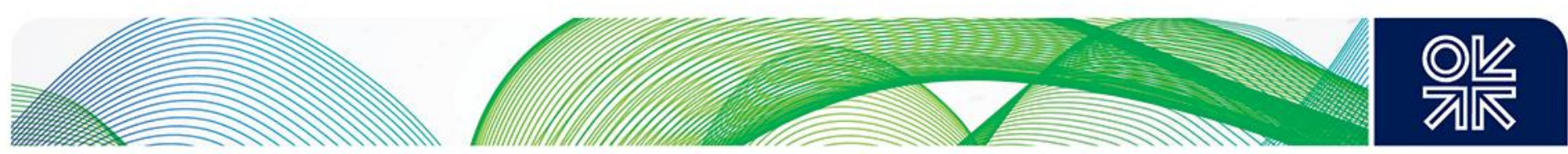

\section{Introduction}

The ambition shown by the European Union (EU) to transform its energy sector and to provide consumers with affordable, sustainable, and secure energy poses a number of challenges to the European electricity system. All three pillars of the EU's energy policy:

- Competition,

- Mitigation of climate change, and

- $\quad$ Security of energy supply

impact notably the future development of European grid infrastructure. In particular, the anticipated (by 2030) 32 per cent share of renewables in final energy consumption (European Commission 2018c) and the reduction of greenhouse gas emissions by 80-95 per cent by 2050 (European Commission 2011) will require extensive infrastructure investments at the European level.

Nevertheless, the future of the European electricity system bears numerous uncertainties. For example, the amount and location of generation, the way in which consumption will develop, the economic framework conditions, and advances in technology, are all ambiguous factors with a potentially strong impact on infrastructure needs and investment decisions. In order to address these future uncertainties, the European Network of Transmission System Operators for Electricity (ENTSO-E) was given the task of developing a set of scenarios within the two-yearly Ten-Year Network Development Plan (TYNDP). The TYNDP explores different plausible future paths and facilitates the assessment of the hardware of the European electricity system - namely transmission and interconnector projects - under various conditions. In this capacity, the TYNDP is viewed by the European Commission (EC) as the central planning tool for the advancement of European grid infrastructure (Interview 19). The TYNDP is an expertise-driven technical plan developed by experts from Transmission System Operators (TSOs). However, it also is part of the wider context of European energy and climate goals and is therefore subject to political expectations. This duality constitutes an interesting case for researching the role of political agendas in highly technical policy areas.

This paper analyses the TYNDP and investigates where in the European energy policymaking arena it is located, by relating it to EU energy policy goals. Moreover, the research examines how stakeholders utilize the TYNDP and what role they ascribe to it. Ultimately, the question of whether the TYNDP is effective in identifying future uncertainties and related challenges for the European electricity system is scrutinized. With regard to methodology, this research applies a combination of document analysis and expert interviews with stakeholders engaged in the TYNDP development process.

The paper contends that both an existing policy congruence and the strong link to the Projects of Common Interest $(\mathrm{PCl})$ process limit the effectiveness of the TYNDP as a strategic policy planning tool and also influence the way in which stakeholders utilize it. In order to improve the plan's effectiveness, the TYNDP should be more closely connected to the software component of the electricity system namely the design and regulation of the future electricity market - to allow for a holistic evaluation of infrastructure projects. In addition, a fundamental reform of European electricity market design and regulation at EU-level is necessary, to enable the identification and allocation of future infrastructure projects.

The research is structured as follows. Section 2 briefly introduces the key actors of European energy policy. The next section then provides an overview of the three pillars of EU energy policy and explores the impact of each on the European electricity system, with a focus on the infrastructure component. Analyses of the TYNDPs from 2012 to 2018, together with an examination of their relationship to EU energy policy goals, are found in the following section. Section 5 investigates how the TYNDP and its scenarios are utilized by various stakeholders. The results of the analysis are presented in Section 6 . A concluding section summarizes the paper's findings. 

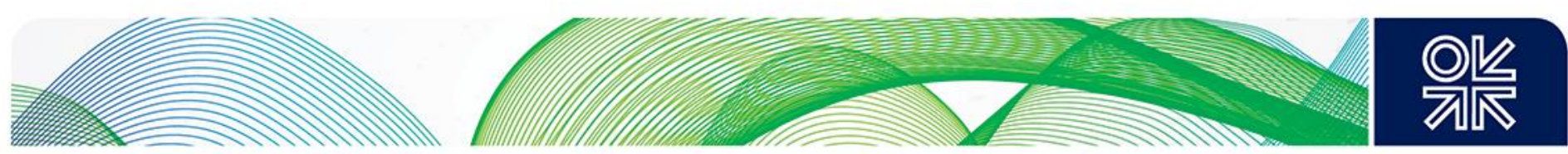

\section{Principal actors in European electricity policy}

European electricity policy is determined by a few key actors who also decide the general energy and climate policy of the European Union. These principal actors are (Schubert et al. 2016):

- the European Commission (EC),

- European member states - through the European Council and the Council of the European Union,

- the European Parliament (EP),

- the Court of Justice of the European Union (CJEU).

However, in electricity policy particularly, two additional actors play a vital role in the development of policies at the European level (Buchan and Keay 2015), namely:

- the Agency for the Cooperation of Energy Regulators (ACER),

- ENTSO-E.

\subsection{European Commission}

The EC is the central promoter of reforms in the European electricity system (Buchan and Keay 2015). Throughout the 1990s and until the third liberalization package in 2009, European electricity policy was focused on liberalization and marketization, which are the Commission's key competences (Talus and Aalto 2017; Schmidt 1998; Domanico 2007; Eikeland 2011).

Through its right of initiative, the Commission assumes the role of a policy entrepreneur and stimulates the development of policies at the European level (Maltby 2013). In electricity policy, this became especially apparent in the EC-driven liberalization of the European electricity industry. Besides its right to initiate policies, the Commission has also made use of antitrust investigations against national energy champions, and also of infringement proceedings against a number of member states. The result of the Commission's efforts were the energy packages that were passed in 1996, 2003, and 2009. Fundamentally, these reforms re-structured the sector and resulted in a new mode of EU electricity policymaking (Buchan 2015; Eikeland 2011). In addition, the Commission - through white papers, policy proposals, and communications - asserts its ideas and policy objectives into the European energy policy discussion. Examples of this are the 2020 Energy Strategy (European Commission 2010), the Energy Roadmap 2050 (European Commission 2011), and, more recently, the Energy Union proposal (European Commission 2015b) and the Winter Package proposals (European Commission 2016a).

Within the Commission (since the Treaty of Lisbon came into force) the Directorate General for Energy (DG ENER) is principally in charge of energy and electricity policy. However, overlaps exist - mainly with the Directorate Generals for Competition (COMP), Climate (CLIMA), Enterprise and Industry (ENTR), and Environment (ENV) (Schubert et al. 2016). In 2014, EC President Jean-Claude Juncker appointed Maroš Šefčovič as Commission Vice President for Energy Union (Juncker 2014). His main tasks - the realization of both the Energy Union (see Section 3) and a progressive climate policy - are to be carried out by coordinating the work of the different DGs involved in energy matters.

Notwithstanding the more active role that the EU member states have assumed in European energy policy since the 2000s (see Section 2.2), the Commission has managed to largely retain its policy initiative capabilities. This is due to an increasingly cooperative working relationship with the European Council (achieved through both formal and informal procedures), as well as to the EC's technical expertise, on which the member states rely. For instance, the Commission's policy goals are often embedded in the European Council conclusions that address energy policy matters (Thaler 2016).

Ultimately, the EC oversees the progress made by member states in reaching the 2030 targets for renewable energy and energy efficiency, and also acts as a policy coordinator (Talus and Aalto 2017). 

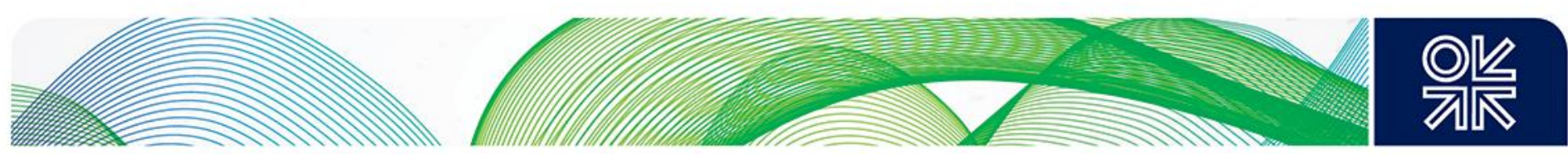

\subsection{EU member states}

Historically, the member states have been reluctant to cooperate with each other and create a common European electricity policy. National governments feared a loss of sovereignty in this strategic sector, and were unwilling to transfer competences to the European level (Eising and Jabko 2001). An example of this unwillingness is the lengthy negotiation process that preceded the adoption of the first electricity liberalization package in 1996. Only through applying the EU's competition law did the EC persuade member state governments to take the first step toward a European electricity policy (Schmidt 1998).

On the one hand, sovereignty over national electricity policy lies with member states. According to Article 194 of the Treaty on the Functioning of the European Union (TFEU), the choice of the design of energy structure, electricity generation mix, exploitation of natural resources for energy generation, external energy relations, and taxation are all exclusive competences of the member state governments (Talus and Aalto 2017).

On the other hand, the general approach of member states towards the idea of European energy and electricity policies changed in the 2000s. The decreasing production of European natural gas and oil, the economic crisis in 2007/8, and tensions with external energy partners in the form of the RussiaUkraine gas disputes in 2006/2009 resulted in a reassessed approach. As the European Commission lacked the necessary competences, the European Council became the primary forum in which governments were able to engineer a collaborative European energy policy in an intergovernmental mode (Thaler 2016). To elaborate, in the European Council meetings of 2005 (Council of the European Union 2005), 2007 (Council of the European Union 2007), and 2013 (European Council 2013), EU member states agreed on the three interlinked objectives of a European energy policy (competitiveness, sustainability, and security of energy supply) and generally consented to the fact that European energy issues should be tackled by a more integrated approach (Thaler 2016).

Close cooperation between the European Commission and member states remains in place. For instance, the Energy Union - as proposed by the Commission (European Commission 2015b) and endorsed by the European Council (European Council 2015) - was developed to ensure close collaboration, without shifting sovereignty from the national to the European level (Pellerin-Carlin 2017; Thaler 2016).

Another institution where member states develop and discuss energy and electricity policies is the Council of the European Union (the Council). The Council's Transport, Telecommunications and Energy Council (TTE) deals with energy matters at the ministerial level of member state governments. Since the TTE meets regularly, representatives of member states are constantly exchanging ideas. Within the TTE, the Working Party on Energy deals mostly with technical issues, such as electricity interconnections and security of supply, which are then proposed to the Council and to the EP for potentially binding decisions (Schubert et al. 2016).

\subsection{European Parliament}

The significance of the EP in EU decision-making procedures has increased in line with the 1993 Maastricht Treaty; its impact on energy policy in general, and on electricity policy specifically, can be seen mainly through its function as a co-legislator, together with the European Council (Talus and Aalto 2017). The Parliament reviews EC proposals and then discusses amendments in its Committees. The proposals are then adopted in the plenary sessions. This process can prove to be lengthy; this is because the EP, in its current composition, is fragmented and, with regard to energy policy, there are divisions that run through both party and member state affiliations (van Hulten and Sitter 2017). In addition, the Parliament can also adopt non-binding resolutions and opinions, in which it expresses concerns or identifies policy issues to be addressed by the Commission. For example, in its 2015 resolution Towards a European Energy Union (European Parliament 2015), the EP comments on the Commission's Energy Union Package (European Commission 2015b). The EP highlights, among other 

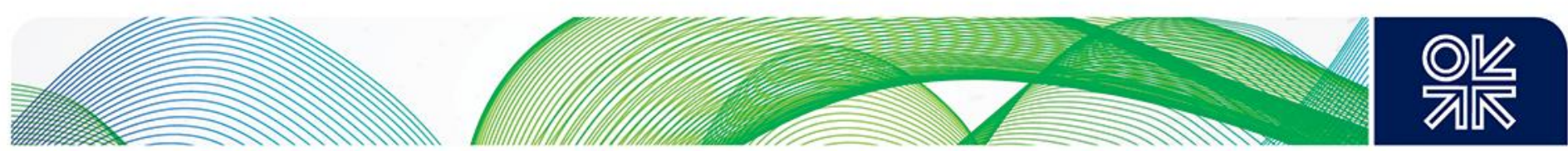

things, the importance of investments in the European electricity market and the necessity of electricity interconnections.

\subsection{Court of Justice of the European Union}

While the CJEU is not a proactive policymaker, its rulings and definitions have shaped European electricity policy substantially, and they continue to do so (Schubert et al. 2016). For example, in 1994 the EC brought competition infringement procedures to the Court, which then defined electricity as a good which is subject to internal market rules (case C-393/92); this in turn put pressure on member states to adopt the first liberalization package (Schmidt 1998). Recently, in 2011 and following the Commission's intention to enforce the third liberalization package, 15 infringement procedures against member states were brought before the Court urging governments to speed up implementation (Talus and Aalto 2017).

In addition, the CJEU validated national subsidies for renewable energy (case C-573/12) and thus potentially obstructed the further development of the internal market for electricity (Schubert et al. 2016).

\subsection{ACER}

The Agency for the Cooperation of Energy Regulators was established by the Treaty of Lisbon, and its competences were defined in the third liberalization package. It provides a coordination and cooperation platform for national regulatory authorities (NRAs) in both the electricity and gas sectors. As a formal EU agency, it advises the Commission on technical issues, and is required to promote the completion of the internal energy market, through activities such as coordinating the creation of European network rules (Labelle 2017). The agency monitors the cross-border activities of TSOs and plays a crucial role in advancing the European electricity market via setting a framework of guidelines for pan-European network codes (Buchan 2015).

However, ACER is not itself a European regulator, and its authority over NRAs is limited to cross-border connections and regulations between member states. Regulatory authority at the national level remains with the NRAs. As a result, ACER chiefly contributes to European electricity making through its opinions, recommendations, and market monitoring reports (Hancher and Salerno 2017).

The EC's Clean Energy Package (alias the Winter Package, European Commission 2016a) foresees a strengthened role for ACER. The Agency should gain greater power to oblige member states to cooperate, and also to maximize the utilization of interconnections. In addition, Regional Operation Centres (ROCs) for TSOs, as proposed by the Commission, would be monitored and coordinated by ACER (Buchan and Keay 2016). ${ }^{1}$

\subsection{ENTSO-E}

The European Network of Transmission System Operators for Electricity coordinates the completion and functioning of the internal market for electricity and was institutionalized in the third liberalization package (European Parliament and Council of the European Union 2009b). The Network determines European cross-border infrastructure investments and also promotes electricity grid interconnections and the physical functioning of the market (Schubert et al. 2016). For instance, ENTSO-E designs the two-yearly TYNDPs and the European Network Codes, in order to facilitate the functioning and advancement of the European electricity market (Vinois 2017). In this capacity, ENTSO-E provides the technical expertise for the integration of member states' electricity markets (see Section 4.1).

Unlike ACER, ENTSO-E is not an EU agency. It is, rather, a member-based organization. Its members are the TSOs from EU states as well as from neighbouring countries (in total 43 TSOs from 36 countries, ENTSO-E 2018a). With regard to its institutional position: ENTSO-E is monitored by ACER and its

${ }^{1}$ The Clean Energy Package has not yet (December 2018) been translated into EU legislation. 

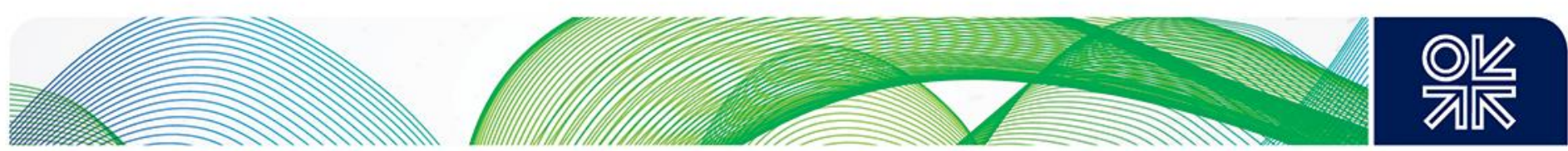

proposals are submitted to the Commission for approval. In addition, the EC sets the priorities for the European Network Codes (European Parliament and Council of the European Union 2009b).

The Clean Energy Package (European Commission 2016a) envisions extended competences for ENTSO-E, for instance with regard to adequacy assessment and capacity remuneration mechanisms. Moreover, the anticipated establishment of ROCs will add an institutional layer between ENTSO-E and the TSOs (Hancher and Salerno 2017). However, TSOs are sceptical about the creation of ROCs as this would transfer their competences to a superior level and raise questions of political accountability in the event of a blackout (Interviews 12, 15).

\section{EU energy and electricity policies}

European energy policy principally rests on three pillars: provision of affordable energy for households and industry, mitigation of climate change, and a secure supply. In order to reach these goals, the EU aims respectively to: finalize the internal energy market, decrease greenhouse gas emissions and boost energy efficiency, and reduce energy import dependency and diversify suppliers (Buchan 2009; Helm 2012; Schubert et al. 2016).

These three objectives, however, were developed neither simultaneously nor harmoniously. In the 1990s, EU competition law and, subsequently, EU environmental policy, shaped the European energy policy agenda (Schmidt 1998; Biesenbender 2015). Nevertheless, competences in energy policy remained exclusively at the member state level until the first liberalization package was passed in 1996; this launched a gradual Europeanization of the policy area. The security of supply framework gained weight in the discussion of a European energy policy in the 2000s, in light of rising oil and gas prices, the accession of eastern European countries with a particularly high energy import dependency on Russia, and the Russia-Ukraine gas disputes (Helm 2012). Energy was eventually elevated into primary EU law in the Treaty of Lisbon in 2009.

Naturally, the three energy policy objectives can be at odds with each other. For example, national subsidy schemes in the form of feed-in tariffs (FiTs) (supporting electricity generated from climateneutral renewable energy sources) stand directly against the creation of a European internal market for energy (Buchan and Keay 2015). On the other hand, the different objectives can also act together on multiple levels. In the European Commission's view, an integrated market increases both supply security and climate mitigation - the resulting efficiency gains, together with the deployment of renewable energy sources, lead to a decreased import dependency on fossil fuels (Fischer 2017; Schubert et al. 2016).

The European Commission has continuously advocated the creation of a more comprehensive and European energy policy. Key documents are the communication An Energy Policy for Europe (European Commission 2007), the Climate and Energy Package (2008)2, the Energy Roadmap 2050 (2011), the Energy Union Package (2015), and the Clean Energy Package (2016). The last two policy documents, in particular, emphasize an inclusive approach to a European energy policy which aims to integrate its three pillars more effectively (Vinois 2017; Buchan and Keay 2016). The policy documents mentioned here will be discussed in detail in the following sections. 

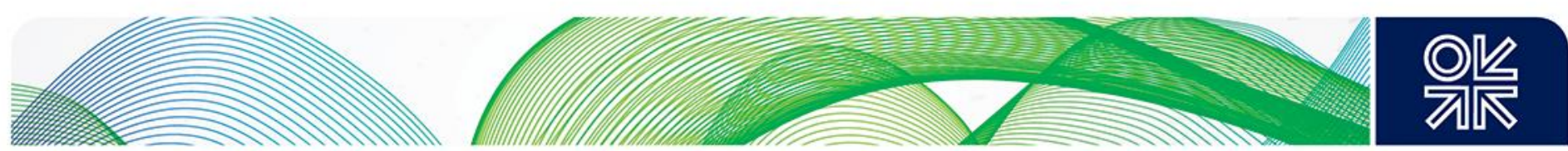

\subsection{Competition}

Competition and the internal market are the central instruments in European energy policy (Peng and Poudineh 2017; Crisan and Kuhn 2017).

In general, a fully functioning market for energy would significantly contribute to the two other energy policy goals (climate change mitigation and security of supply). To elaborate, in such a market, consumers would be able to choose from a greater diversity of suppliers and undermine the power of natural gas importers (such as Gazprom), thus enhancing security of supply. Second, competition between energy producers would drive efficiency and reduce costs, and potentially also reduce both import dependency (of oil and natural gas) and $\mathrm{CO}_{2}$ intensity (Helm 2014). In addition, an interconnected market allows for the integration of large-scale renewable energy sources and a more effective balancing between production and consumption across Europe (ENTSO-E 2014a).

From a policymaking perspective, competition rules are the strong suit of the European Commission it possesses exhaustive competences in this area. For instance, the EC can launch infringement proceedings against member states in cases where EU competition law is not correctly applied; this in turn can eventually lead to a court filing at the CJEU. ${ }^{3}$ Moreover, the Commission can fine individual companies for the violation of monopoly rules. ${ }^{4}$ By applying EU competition rules, the EC has aimed to frame energy policy around the liberalization of the sector, which has ultimately resulted in the three liberalization packages (1996/98, 2003, and 2009) (Schubert et al. 2016).

\section{Hardware and software - the status quo}

The internal market for energy consists of a software and a hardware component. On the software side, moderate progress has been achieved. The unbundling of vertically integrated energy companies and guaranteed access to gas and electricity grids for third parties has opened the market. Consumers are now free to choose their electricity and gas provider, resulting in increased competition between suppliers. Moreover, the coupling of energy markets, the implementation of Network Codes, and coordination efforts by ACER facilitate the trading of energy across Europe (Crisan and Kuhn 2017). Nevertheless, considerable flaws in the design of the European market, particularly in electricity, still exist (Peng and Poudineh 2017). In other words, and partly due to the aforementioned national FiTs for renewables, electricity prices are distorted. For instance, retail prices for consumers vary considerably from country to country (Schubert et al. 2016). Moreover, the gap between wholesale and retail prices is widening and price signals are not passed on to consumers, thus lowering the incentive for the desired demand-side response measures, and undermining the EU policy goal of affordability. Negative wholesale prices for electricity occur frequently, signalling a dysfunctional market. In addition, the energy-only market does not currently provide price signals that are capable of triggering investment in the necessary energy infrastructure. This is true for both dispatchable (mainly fossil combustion) and also for the non-dispatchable (mainly solar and wind) generation plants which are essential to a decarbonized power system (Keay 2016). Ultimately, with 28 NRAs, electricity market regulation in Europe remains focused on the national level, as ACER is not a European regulator but a cooperation platform for national regulators. A stronger role for ACER, as proposed in the EC's Winter Package (European Commission 2016a), could facilitate the transformation of the agency into a European regulator; this would enable it to tackle congestion issues and the underutilization of cross-border interconnections more effectively.

The underlying problems are structural, in the sense that the current market design is not able to facilitate the desired competition and investment while at the same time guaranteeing the large-scale integration of renewable energy (Glachant 2016; Keay 2016). The Commission, too, has articulated its

\footnotetext{
${ }^{3}$ In 2011, the Commission launched 38 infringement proceedings, out of which 15 were handed over to the CJEU, Talus and Aalto 2017.

${ }^{4}$ In 2009, the gas companies E.ON and GDF Suez were fined $€ 1.1$ billion for unfair competition, Schubert et al. 2016.
} 

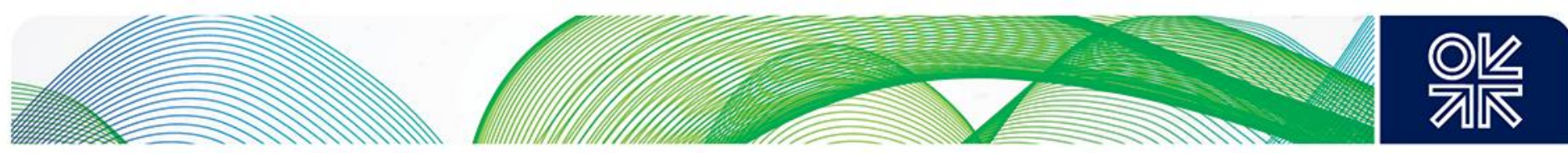

own uncertainty about future energy market designs (European Commission 2015c). For the software component to contribute effectively to a fully functional internal market for energy, substantial reforms are needed. Different pathways for reforming the software are possible; these range from a set of amendments as proposed by the EC in the Winter Package (see below), to a more fundamental revision toward a two-tier market design (Keay and Robinson 2017), a decentralized design (Kristov et al. 2016), or an energy-and-delivery market design (Pierpont and Nelson 2017), to name some recent suggestions. As the current market design is closely linked to the way in which existing infrastructure was planned in the past, a revised market design would also require the hardware component of the electricity market to be updated.

The second and complementary component for a functioning European energy market is hardware meaning energy transport infrastructure. The hardware aspect is particularly important for the trading of gas and electricity since both are grid-bound and need a physical interconnection between buyer and seller (unlike oil). With regard to electricity in Europe, cross-border interconnectors are key to building a true European grid and for a European market to materialize. However, the sector has developed over time in such a way that the EU currently has 28 national electricity grids which are divided into five regional groups (Schubert et al. 2016). While the cross-border exchange of electricity has been increasing over the last 20 years, congestion between member states still exists, impeding the free trade of electricity between national markets. In addition to the aforementioned software flaws, this congestion is mainly due to underdeveloped physical interconnection capacities which have not kept pace with the increasing share of intermittent renewables; for optimal grid integration of renewables more cross-border trading is required (see Section, 3.2).

In order to facilitate the building of electricity interconnections, the Commission has developed a set of tools and measures which were translated into binding EU law via Regulation (EC) No. 347/2013 (the TEN-E Regulation, European Parliament and Council of the European Union 2013). The central instrument here is the identification and realization of Projects of Common Interest (PCls). In electricity, these projects include transmission lines and storage facilities. The objective of the PCls is to physically connect national electricity markets and to construct infrastructure where it will have the biggest impact on the achievement of EU policy goals, namely the provision of secure, affordable, and sustainable electricity (European Commission 2018d). The underlying idea is for the TSOs to focus on projects that will contribute most to

$$
\begin{aligned}
& \text { - } \quad \text { cross-border trading, } \\
& \text { - } \quad \text { mitigation of capacity congestions, and } \\
& \text { - } \quad \text { the guaranteeing of a secure supply of electricity. }
\end{aligned}
$$

In order to trigger the necessary investment in the PCls, the Commission provides a set of incentives for TSOs and third-party project promoters. PCls enjoy priority over other projects at the national level, are granted a streamlined permitting process, and receive significant EU public funding and financing (Buchan and Keay 2015). For instance, under the European Commission's Connecting Europe Facility (CEF), 50 per cent of a PCl's total project cost is covered by a grant (see Section 5). The PCls have to be located within the 12 different priority corridors set out in the TEN-E Regulation (Crisan and Kuhn 2017). The PCI selection process, championed by the EC, is based on ENTSO-E's TYNDP as it uses the same cost-benefit analysis (CBA) and all potential PCls must have been included in the previous TYNDP project list (Crisan and Kuhn 2017). Since 2014, significant responsibility for the hardware component of the internal market for energy (see Section 4.2) has been assigned to the TYNDP scenario development process, on which the selection of future infrastructure projects is based. The current $\mathrm{PCl}$ list includes 106 electricity transmission and storage projects (European Commission 2018a). 

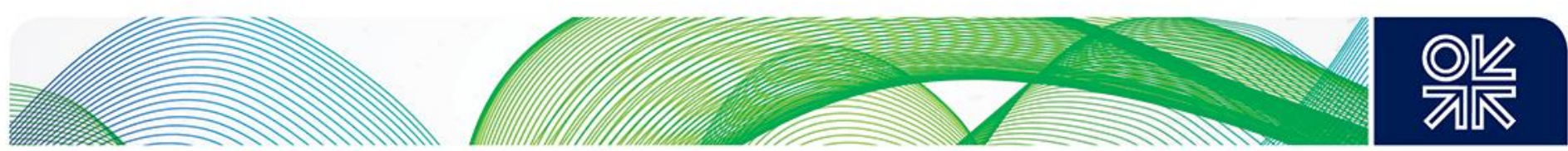

\section{Policy goals - impact on electricity}

The Union's central policy goal in competition is the completion of the internal energy market. With regard to electricity, the European Commission has acknowledged that the current market design needs to be adapted to the more flexible nature of the electricity sector. Hence the EC proposed, in its Winter Package (COM(2016) 864, $\operatorname{COM}(2016) 861, \operatorname{COM}(2016) 863), \operatorname{COM}(2016) 862)$, a set of measures to improve, primarily, the software of the existing market structure. Among these measures are (Buchan and Keay 2016):

- more effective scarcity pricing,

- a move towards shorter-term trading in wholesale markets,

- $\quad$ improved member state coordination of capacity mechanisms and RES support schemes (with minimized market distortion and approved by the respective NRAs), and

- a significant amplification of ACER's competences to enable true European market regulation.

In addition, the aforementioned ROCs are envisioned to play a greater role in advancing the software component - for example through coordinated system operation, capacity calculation, and risk preparedness (European Commission 2016c). The EU inter-institutional negotiations over the proposed measures are ongoing (December 2018).

In terms of goals for the development of electricity hardware, the EU has established minimum interconnection targets. As part of the Energy Union package, member states are supposed to install 10 per cent cross-border capacity (as a proportion of their total generation capacity) until 2020 and then 15 per cent until 2030 (European Commission 2015a). Moreover, the EC has proposed a threshold for wholesale market price differences. If the price differential between member states, regions, or bidding zones is above $2 € / M W h$, the respective member states are encouraged to build more interconnectors (European Commission 2017b).

In addition, the Commission has set up the Commission Expert Group on electricity interconnection targets, a rather exclusive forum consisting of 17 experts from ACER, ENTSO-E, the European Network of Transmission System Operators for Natural Gas (ENTSOG), TSOs, interest groups, academics, and technology companies. The expert group has met 14 times between October 2016 and October 2018 in order to 'guide the development of trans-European electricity infrastructure' (Commission Expert Group on electricity interconnection targets 2017).

By 2017, 11 member states had yet to reach the 10 per cent cross-border capacity threshold, but of these, seven were on a trajectory to achieve it by 2020 (European Commission 2017b). The interconnection targets will primarily be achieved with PCls.

To sum up, the competition pillar of European energy policy has two implications for electricity policy:

1. The need for an inclusive progression of the software component, in order to create a European market. This entails either a reform or a complete overhaul of the existing market design, accompanied by the further development of network codes and national electricity market coupling.

2. The construction of physical cross-border interconnections. This is quantified through the targets for national electricity grids of 10 per cent and 15 per cent by 2020 and 2030, respectively.

\subsection{Mitigation of climate change}

With the entering of climate change onto the political agenda, sustainability became a driver of European energy policy in the 1990s (Biesenbender 2015). The European Commission introduced, in 1997 , the objective of increasing the share of electricity produced from renewable sources in order to 

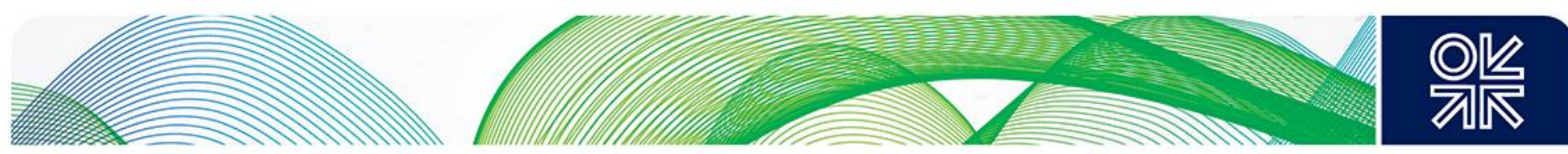

lower emissions, reduce import dependency, and create economic growth (European Commission 1997). At the same time, the EU would be at the forefront of mitigating climate change. In the Renewable Energy Directive in 2009, the member states agreed to binding targets for 2020 (European Parliament and Council of the European Union 2009a):

- a 20 per cent reduction of greenhouse gas emission (compared to 1990),

- a 20 per cent share of renewables in energy consumption,

- $\quad$ reduction of total energy consumption by 20 per cent through efficiency gains.

The Directive evolved into an important pillar of European energy policy and became the central instrument for the reduction of carbon emissions (Schubert et al. 2016; Buchan and Keay 2015). This is partly due to the fact that the EU Emission Trading System (EUETS) has not yet proved to be an effective mechanism and rather negates renewables deployment (Helm 2014). The Renewable Energy Directive was supplemented by the 2030 Energy Strategy in 2014 (European Council 2014); this defines a goal of a Europe-wide 27 per cent share of renewable energy of final consumption and a 40 per cent reduction of overall $\mathrm{CO}_{2}$ emissions.

\section{Policy goals - impact on electricity}

The reduction of greenhouse gas emissions and the goals for renewables share have a particularly strong impact on the European power sector, and are therefore key elements of EU electricity policymaking. The 2009 Directive set individual national targets and thus spurred the development of different renewables support schemes in the member states (Schubert et al. 2016; Helm 2014). However, this situation is in direct conflict with the principle of competition and the goal of creating an internal market for electricity.

In addition, the increasing share of renewables production has impacts on both the software and the hardware components of the European electricity system. With regard to software, non-dispatchable renewables with very low marginal costs, supported by subsidies, disrupt the traditional market - which was designed for electricity produced by large, centralized fossil fuel power plants (Peng and Poudineh 2017). This results in incorrect price signals for investment, a large gap between wholesale and retail prices, and the introduction of market-distorting instruments such as capacity mechanisms at the national level.

On the other hand, the increasing share of electricity from renewables is having a stark impact on the infrastructure of the European electricity system. Since electricity produced from wind and solar, the two largest sources of renewable energy in Europe, is intermittent and often supported by national $\mathrm{FiTs},{ }^{5}$ daily and seasonal fluctuations of supply occur. In an electricity grid, these fluctuations need to be balanced and matched with equal demand. This can principally be achieved in three ways:

- by promoting demand flexibility to match the fluctuating supply,

- by the deployment of large-scale electricity storage, or

- via the integration of various supply and demand centres.

For technological and economic reasons, the first two measures are not yet a viable European solution, particularly for seasonal fluctuations. Hence, the EU pursues the strategy of improved integration: in order to accommodate intermittent electricity and to match demand and supply on a European scale, extensive cross-border interconnection infrastructure and a 'smarter grid' is pursued (European Commission 2011, 2015a; Crisan and Kuhn 2017). This is also necessary because the centres of generation and demand are geographically distant, as the majority of European renewable electricity is 

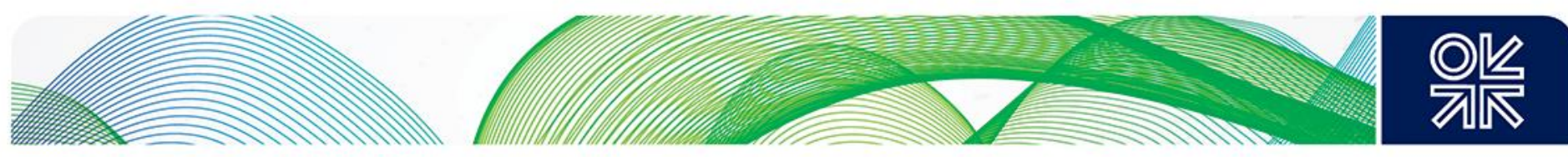

currently produced at the periphery (for example around the North Sea area) and needs to be transported to centres of demand, for example in south Germany and north Italy.

To sum up, the sustainability pillar of European energy policy requires the current market design to be reformed (software) and the electricity infrastructure (hardware) to be expanded and better integrated. In fact, with an anticipated minimum share of 45 per cent renewables in the electricity sector by 2030 (European Commission 2014), considerable investment in transmission and interconnection infrastructure is needed - as outlined in each scenario in the EC's Energy Roadmap 2050 (European Commission 2011).

\subsection{Security of supply}

In the light of the accession of Eastern European member states in 2004 and 2007, and particularly considering the Ukraine-Russia gas crisis in 2009 , security of energy supply came to the focus of European policymakers (Buchan 2015). Since then, security of supply has become the central theme, and arguably the ultimate goal, of European energy policy (Schubert et al. 2016). This development is reflected in the Commission's Energy Union (European Commission 2015b) strategy, in which a secure energy supply plays a pivotal role and is closely linked to foreign policy issues (Fischer 2017; Franza and van der Linde 2017). This rise of supply security on the EU's energy policy agenda is associated primarily with natural gas imports and has resulted, for example, in the creation of the Gas Coordination Group in 2011.

The EU's striving for sustainability has also had an increasing impact on the security of supply component. This impact is twofold:

- The accomplishment of the Union's efficiency and renewable energy goals would decrease its import dependency on fossil fuels and therefore increase supply security (Fischer 2017).

- The increasing share of intermittent electricity from renewables can have negative effects on system stability and adequacy. Therefore, security of electricity supply has received particular attention at both the national level and in recent EU policy documents (for example in the Clean Energy Package (European Commission 2016a) and the Communication on strengthening Europe's energy networks (European Commission 2017b)).

\section{Policy goals - impact on electricity}

The volatile, less predictable, and decentralized character of renewable electricity generation strains the existing grid infrastructure that was designed for a system based on dispatchable, centralized generation. As a result, European grids are running closer to their operational limits and, due to their interconnectivity, a potential disruption could have severe Europe-wide consequences ${ }^{6}$ (ENTSO-E 2018c).

As large-scale electricity storage and demand response are not yet available, member states have introduced capacity mechanisms at the national level in order to counter the intermittency of renewable electricity and to guarantee security of supply. While these mechanisms enable the balancing of generation fluctuations in the grid through dispatchable (primarily gas) power plants, their payment schemes distort the internal market for electricity. The European Commission aims to coordinate these different schemes and to smooth out national differences (Glachant 2016).

At the European level, ENTSO-E ensures the security of electricity supply by facilitating the harmonization of planning and operating guidelines and is, in particular, promoting adherence to the $\mathrm{n}$ 1 criterion. ${ }^{7}$ Another measure for increasing the security of electricity supply at the European level is

\footnotetext{
${ }^{6}$ As was the case during the European blackout in November 2006, UCTE 2007.

${ }^{7}$ This guarantees system stability when one transmission line or major generating unit goes offline.
} 

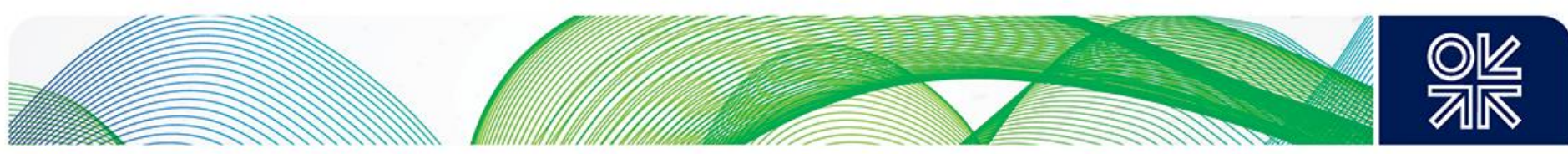

the expansion of cross-border interconnections - a strategy actively pursued by the European Commission (see for example European Commission 2017b). In particular, the interconnection targets of 10 per cent and 15 per cent, primarily through the construction of the aforementioned PCls, are intended to contribute to electricity supply security. In addition, the EC has proposed two thresholds in order to spur the construction of interconnections: member states with a nominal transmission capacity below 30 per cent of their peak load and/or below 30 per cent of their installed renewable generation capacity 'should urgently investigate options of further interconnectors' (European Commission 2017b, p. 12).

To sum up with regard to electricity policy, the security of supply pillar of European energy policy results in increased harmonization efforts and the promotion of more cross-border interconnections.

\subsection{Summary of EU policies}

This review of the three pillars of EU energy policy and the associated goals for a European electricity policy shows that a more comprehensive physical integration of national electricity grids is needed. In fact, it is a key component for the achievement of each of the three policy goals - a competitive market, the mitigation of climate change, and a secure supply. Hence, the construction and improvement of cross-border interconnections is the common denominator and core element of a European electricity policy. Ultimately, this highlights the significance of the $\mathrm{PCI}$ process in EU electricity policymaking. The $\mathrm{PCls}$ aim to trigger investments in those infrastructure projects that would contribute most to the three policy goals. Consequently, the European Commission attributes to the $\mathrm{PCl}$ selection process a substantial importance for the European electricity system.

ENTSO-E's Ten-Year Network Development Plan is the central tool for analysing the future requirements of the European electricity system and for identifying the PCls.

\section{Correlation of TYNDP scenarios and EU policies}

This section analyses the different TYNDPs and how they relate to the European goals in energy and electricity policy described above.

\subsection{Introduction to TYNDPs}

The development of a two-yearly community-wide network development plan was laid out as one of the tasks of ENTSO-E in its founding document. This task consists of:

'modelling of the integrated network, scenario development, a European generation adequacy outlook and an assessment of the resilience of the system' (European Parliament and Council of the European Union 2009b, Art. 8.10).

The TYNDP aims to identify challenges for the future development of the European grid, points out investment needs, and enables the assessment of projects with European significance on the basis of a common cost-benefit analysis (CBA) methodology. The future of the electricity system in Europe entails numerous uncertainties such as: future amount, location and modes of generation, development of consumption, economic framework conditions, and $\mathrm{CO}_{2}$ price. As electricity infrastructure is capital intensive and has long planning, permitting, construction, and operational horizons, these uncertainties can effectively stall the necessary investment decisions. Therefore, the TYNDP uses a set of scenarios in order to address these uncertainties and to provide decision makers with an overview of plausible futures (ENTSO-E 2010).

While the methodology has evolved over the years, the underlying purpose of the TYNDP scenarios has remained largely the same. Rather than attempting to predict the future, the scenarios aim to 

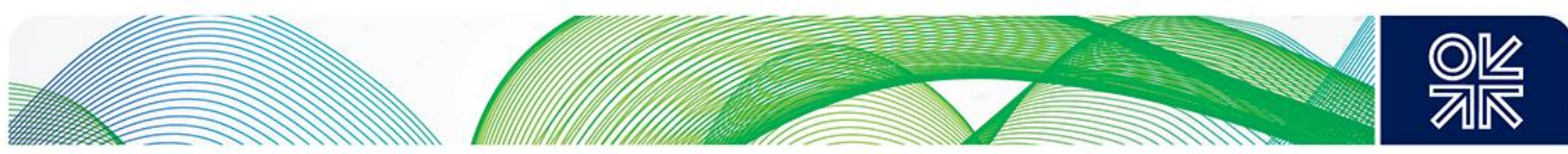

describe a realistic range of possible futures within which the actual future pathway will fall, by using different combinations of assumptions. Based on this range of possible futures, decision makers can then determine infrastructure needs and identify key cross-border projects. In addition, existing or planned projects can be assessed against the range of possible futures (see for example ENTSOG and ENTSO-E 2018; ENTSO-E 2015; 2014a).

In general, the TYNDP scenarios combine a top-down with a bottom-up approach. To elaborate, a topdown approach to scenario building sets a target (such as a policy goal) or a high-level expectation around which the scenarios are then built. A bottom-up approach, in contrast, is based on current trends and typically relies on best future estimations by stakeholders (ENTSO-E 2010). The TYNDP scenarios, specifically, take into account binding policy targets, technology roadmaps, and trends, as well as electricity infrastructure projects that are in the construction or planning stage. The TSOs provide the technical expertise and data for the development of scenarios. TSO experts are also in charge of determining the specific grid development needs for each scenario and are the key actors in the process. In addition, public workshops and consultations are carried out throughout the TYNDP and scenario development process, in order to receive input and feedback from stakeholders (ENTSO-E 2015). Once finalized, the TYNDP is submitted to ACER which gives a (non-binding) opinion and recommendation to the Commission for approval (European Parliament and Council of the European Union 2009b). Based on their technical expertise, ENTSO-E and its members are in charge of developing the TYNDP. Nevertheless, there are also informal engagements of other stakeholders such as interest groups and the European Commission (see Section 5). The EU member states generally engage rather indirectly through $\mathrm{TSOs}^{8}$ and the NRAs represented in ACER.

Once the TEN-E Regulation (No. 347/2013, European Parliament and Council of the European Union 2013) became binding, the TYNDP constituted the basis for the PCI selection process, as any potential transmission or storage PCl had to have been included in the project list of the previous TYNDP. In addition, the $\mathrm{PCl}$ process applies the same CBA methodology as is used in the TYNDP. Notwithstanding its non-binding legal status, this makes the TYNDP and its scenarios a central piece of European electricity policy, as the PCls are the common denominator for the advancement of all three high-level policy goals (see Section 5).

To sum up, the TYNDP is the central planning instrument for advancing the European electricity infrastructure (Interview 19). The core objectives are to identify future challenges to the European electricity system and to determine associated investment needs. These are vital components for the development of a European electricity system. Although the planning of pan-European infrastructure is a technical process driven by ENTSO-E and the national TSOs, the TYNDP is also a political process. This is due to both the importance of electricity infrastructure for each of the three European policy goals outlined above and the significance of TYNDP's strong link to the PCl selection process. This political component is reflected in the scenarios developed in the TYNDP.

\subsection{TYNDP scenarios and EU policy goals}

This section investigates the scenarios developed in the 2012, 2014, 2016, and 2018 TYNDPs and relates them to the European policy goals. The pilot TYNDP 2010 is not considered as it was more a display of existing trends and not at that point a particular planning exercise (ENTSO-E 2010).

\section{TYNDP 2012}

The second TYNDP, in 2012, outlined a set of four visions for 2030 (shown in Figure 4.1). The objective of these visions was to address uncertainties in the development of the electricity system and display

\footnotetext{
${ }^{8}$ The link with a member state government depends on the governance structure of the respective TSO. While some TSOs are publicly listed companies (for example National Grid in the UK), others are effectively state owned (for example PSE in Poland) A state-owned TSO is more closely aligned to the policies of the national government (Interview 4).
} 

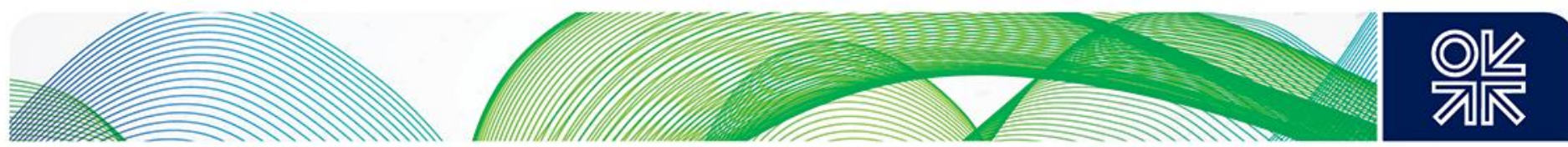

possible energy projections for decision makers. It is assumed that actual future developments will fall within the range of these visions.

The 2030 visions are constructed along two axes: the pace of achievement of the Energy Roadmap 2050 targets and the degree of integration of the internal energy market (ranging from a strong European framework and a well-integrated electricity market on the one hand, to a loose European framework with parallel national policies and less-integrated markets on the other). The four visions are Slow Progress, Money Rules, Green Transition, and Green Revolution.

\section{Figure 4.1: TYNDP 2012 Visions for 2030}

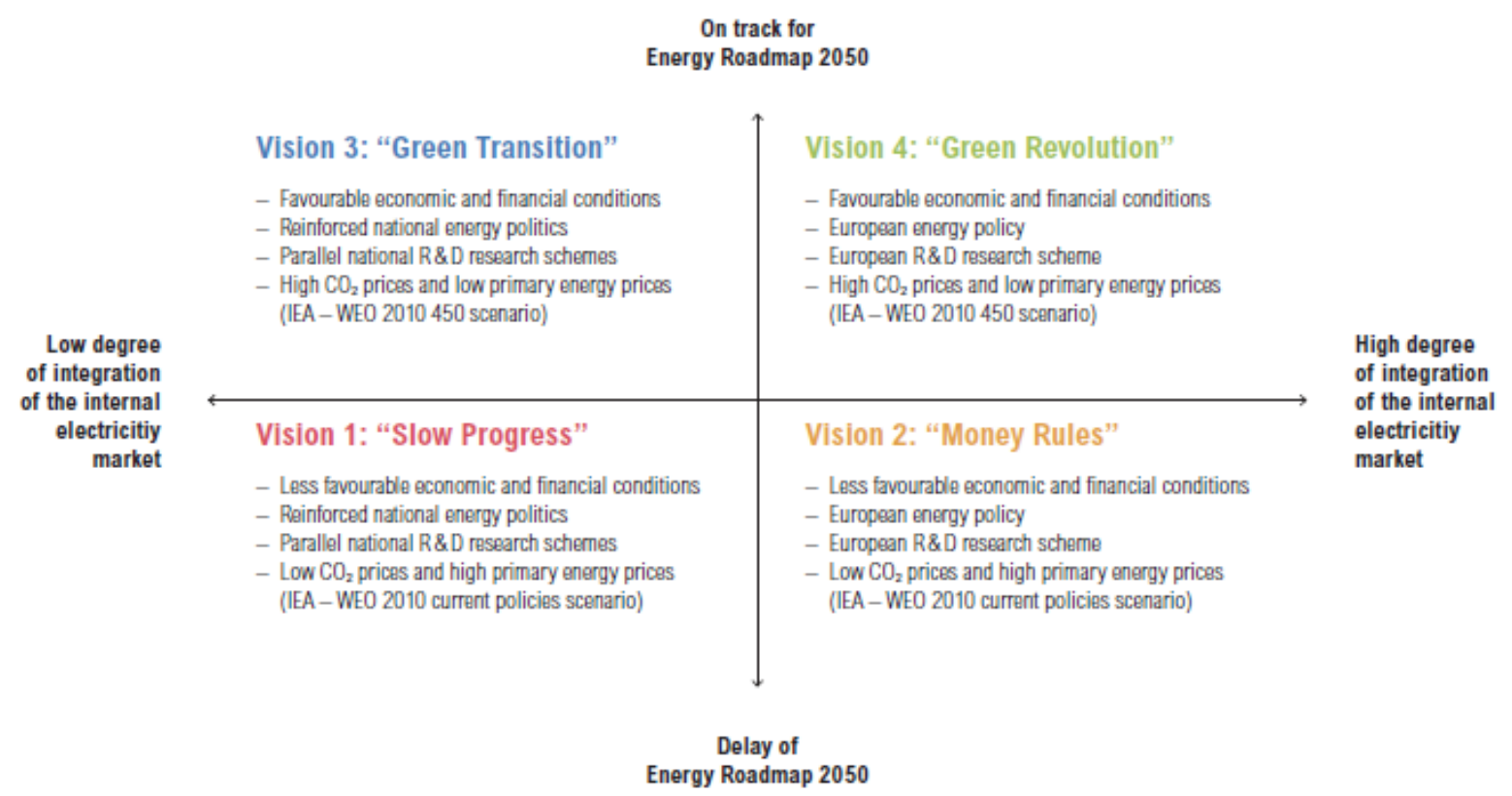

Source: ENTSO-E (2012a, p. 37)

Each of the visions takes into account a set of factors that could impact member state energy policies, electricity demand, and generation and grid development. These factors are, for example, economic development, deployment of electric vehicles, demand response mechanisms, $\mathrm{CO}_{2}$ price, and the development of carbon-capture-and-storage (CCS) technology. In particular, the grid development needs of each vision are articulated by the TSOs at the European and regional level. Ultimately, in all visions, the Renewable Energy Directive targets for 2020 are met (with possible delays) (ENTSO-E 2012a).

In the light of the four visions for 2030, the TYNDP developed two scenarios for 2020. This shorter time horizon reduces uncertainty while simultaneously complying with the trends up to 2030. The two scenarios outline different paths up to 2020 :

- $\quad$ EU 2020 is a top-down scenario that takes the Renewable Energy Directive targets for 2020 (20 per cent reduction in greenhouse gas emissions, 20 per cent share of renewables, 20 per cent reduction in energy consumption), together with the corresponding national energy action plans, as a starting point and describes a pathway to achieve these targets. The $E U$ 2020 is the reference scenario of the TYNDP 2012.

- Scenario $B$ follows a bottom-up approach and, starting from the status quo (2012), is based on the best estimates by TSOs. It takes into account the commissioning of future power 

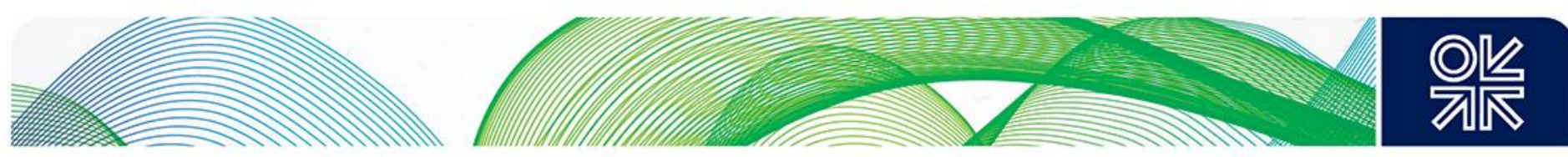

plants, while figures for generation and load are based on national information available to TSOs (ENTSO-E 2012a, 2012b).

The development of the scenarios has been coordinated by ENTSO-E and was conducted by TSO experts in three working groups and six regional groups. Subsequently, the scenarios have been publicly consulted with stakeholders.

The two developed scenarios have had a strong and distinct impact on future grid development. For instance, they assume different shares of renewable electricity, fossil fuels, and nuclear power. Moreover, EU 2020 and Scenario B differ in their assumptions about generation portfolio, demand, and load, with varying implications for grid development needs (ENTSO-E 2012a).

Nevertheless, both scenarios 'eventually rather converge, showing shared consensus regarding achievement of the 20:20:20 objectives' (ENTSO-E 2012b, p. 33). Hence, the two scenarios effectively describe two rather similar pathways towards achieving the EU policy objectives, in this case the Renewable Energy Directive targets. While this was outlined in the TYNDP 2012 objectives (ENTSOE 2012b, p. 9), the fact that the two scenarios are alike poses a potential problem for two reasons:

1. From a scenario development technique perspective, a narrow range of scenarios would conceivably fail to address all possible futures and contingencies (van der Heijden 2005).

2. With regard to the TYNDP, the resilience of the existing and planned grid infrastructure is assessed exclusively against these two scenarios and their particular planning cases (specific contingencies such as season, demand, and weather).

In turn, the need for, and specifics of, future projects are solely based on the two scenarios. Subsequently, the assessment of these projects in terms of their contribution to security of supply, social welfare, and renewables integration, among other factors, is only valid in these two possible futures. The alignment of the two TYNDP scenarios with the 20:20:20 goals could limit the resilience of the projects included, and in fact sets too narrow a corridor for possible future pathways; it thus confines the future design of the European and national electricity grids from both a technical and political perspective.

To sum up, in terms of grid development, the TYNDP 2012 projects an increase in generating capacity that is largely based on the development of renewables. This, in turn, leads to a fundamental relocation of generation, resulting in larger and more intermittent power flows across Europe. Consequently, bottlenecks and investment needs in the grid infrastructure are identified, resulting in more than 100 pan-European transmission projects worth $€ 104$ billion of investments. These investments contribute to all three EU electricity policy goals: European market integration (47 per cent of projects), integration of renewable energy sources ( 80 per cent of projects) and $\mathrm{CO}_{2}$ emission reduction (100 per cent), and higher security of the grid (100 per cent) (ENTSO-E 2012b, pp. 16-17).

\section{TYNDP 2014}

The subsequent TYNDP differs significantly from TYNDP 2012 in two respects: its scenario development methodology and its institutional significance within the EU's energy policy.

The TYNDP extended its time horizon to 2030 and scenarios for 2020 are no longer developed. The four visions for 2030 outlined in the previous TYNDP (Figure 4.1) are elevated into the central scenarios for determining different future paths (see Figure 4.2). This change was largely based on feedback from stakeholders, who requested longer-term and more contrasting scenarios (ENTSO-E 2014a). Hence the TYNDP puts a greater emphasis on stakeholder participation throughout the process and pursues a more holistic scenario development approach. The visions are again designed along the same axes: pace of achievement of the Energy Roadmap 2050 and degree of integration of the European electricity market. However, in contrast to the four visions described in the previous TYNDP, the 2014 edition sketches out the extremes on the two axes, resulting in four contrasting scenarios: Slow Progress, Money Rules, Green Transition, and Green Revolution (Figure 4.2). These are then fleshed out with 

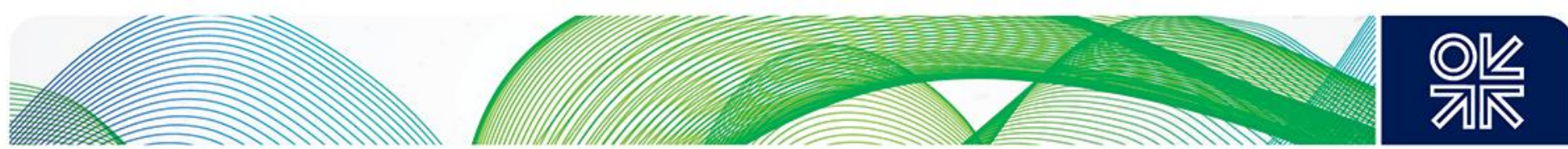

political and economic frameworks, while the respective generation and load characteristics are based on a set of different parameters (such as $\mathrm{CO}_{2}$ price, deployment of electric vehicles, fuel prices, $\mathrm{CCS}$ deployment, and smart grids). The four scenarios differ in terms of future electricity consumption, generation mix, $\mathrm{CO}_{2}$ emissions, electricity prices and, most significantly, renewables deployment. Nevertheless, across all scenarios, $\mathrm{CO}_{2}$ emissions are predicted to fall and the share of renewables to rise.

Figure 4.2: TYNDP 2014 Visions for 2030

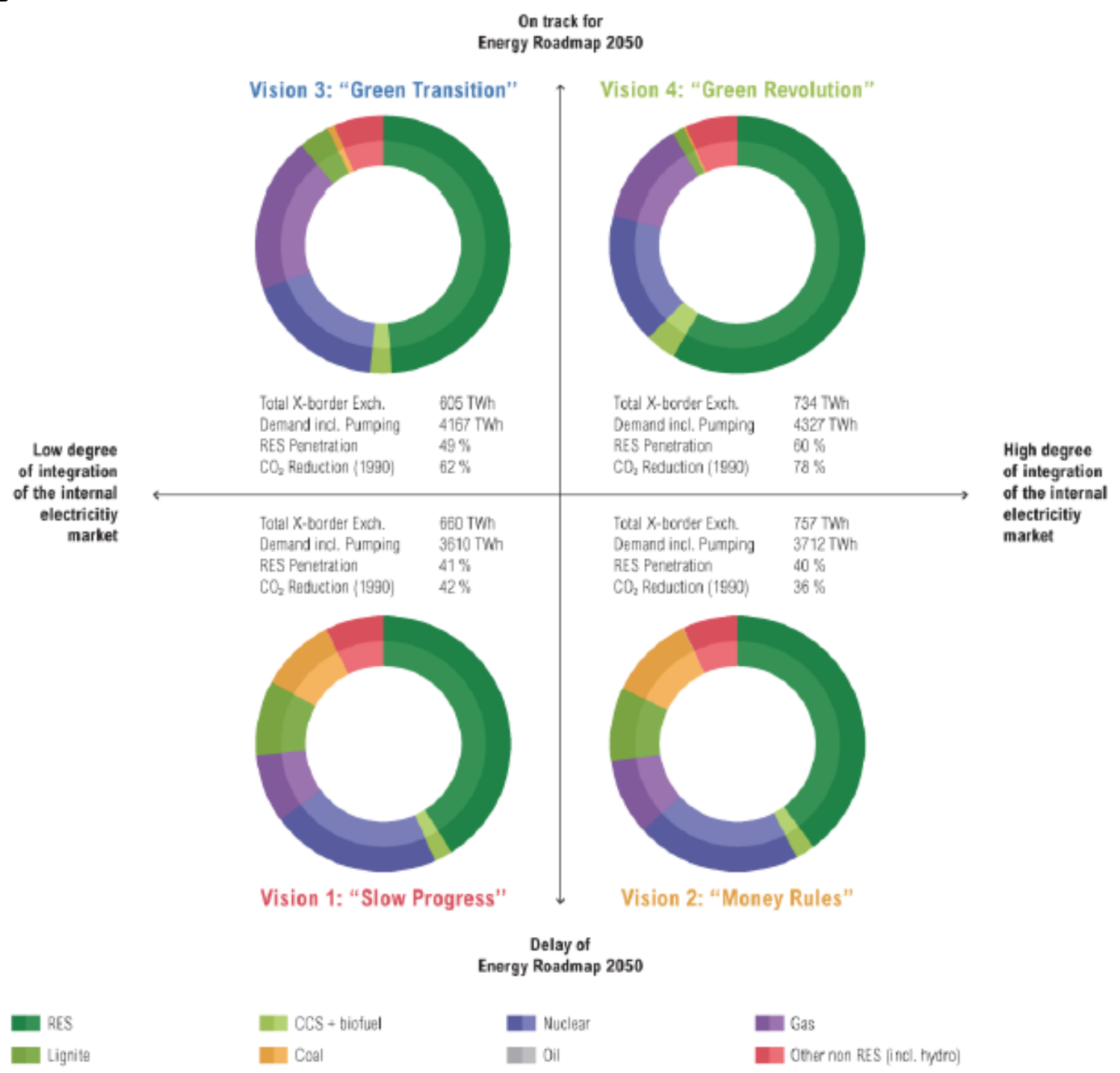

Source: ENTSO-E (2014a, p. 9)

The TYNDP 2014 again uses a combination of top-down (Money Rules, Green Revolution) and bottomup (Slow Progress, Green Transition) scenarios. The primary difference between the two approaches is the strong integration of electricity grids at the European level in the top-down scenarios, versus resolute parallel national policies in the bottom-up scenarios (ENTSO-E 2014b). In comparison to the two scenarios developed in the TYNDP 2012, the 2014 scenarios are evidently more diverse and nuanced, and cover a wider range of possible futures and contingencies. In addition, the evaluation of 

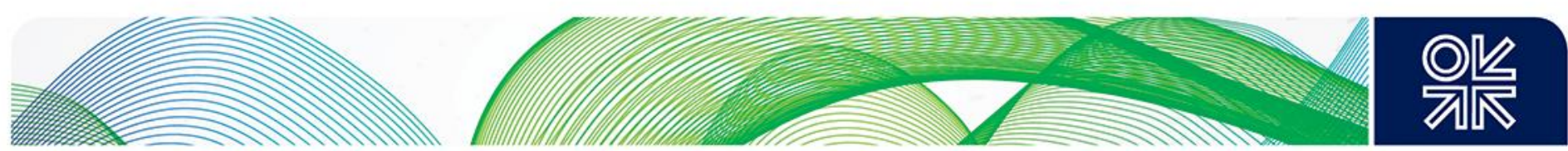

infrastructure projects within these scenarios is arguably more sophisticated as, for the first time, the TYNDP applies a common and quantitative cost-benefit analysis (CBA).

With regard to the EU energy policy goals, all four 2014 scenarios are eventually on track for achieving the Roadmap 2050 objectives, the difference being the slower pace in Slow Progress and Money Rules up to 2030. The projects included in the TYNDP 2014 are evaluated against their respective contribution to the EU energy policy goals in the different scenarios. In particular, projects are evaluated against their contribution to the EU energy policy goals in Vision 1 (Slow Progress) and 4 (Green Revolution): in Vision 1, 44 per cent and in Vision 4, 80 per cent of projects contribute to the integration of renewables electricity into the European grid. On the other hand, 50 per cent of projects in Vision 1 and 92 per cent of projects in Vision 4 assist the mitigation of $\mathrm{CO}_{2}$ emissions. ${ }^{9}$

With the 2014 edition, the institutional significance of the TYNDP grew after the aforementioned EU Regulation 347/2013 on Trans-European Networks in Energy (TEN-E) was passed in 2013. This Regulation strongly promotes the development of cross-border transmission infrastructure in Europe through the process of defining PCls. Moreover, it calls for the development, and sets the requirements, of a standard CBA methodology. The Commission plays an active role in the development of the CBA methodology and gives the final approval (Interview 20). Ultimately, the TEN-E regulation positions the TYNDP as the sole platform for identifying potential PCls, since all future PCls have to be part of the TYNDP's project list (ENTSO-E 2014a).

Nevertheless, the TEN-E Regulation effectively creates a new structure for advancing the hardware component of the European electricity system that is outside the ENTSO-E framework (Glachant 2017). To elaborate, the $\mathrm{PCl}$ process is the selection, evaluation, and possible financing of priority grid investment projects outside the ENTSO-E framework. The PCls are selected and evaluated in four regional groups that are defined in the Regulation. ${ }^{10}$ These groups consist of representatives from: the respective regional TSOs and NRAs, ACER, member states, and project promoters and each is led by an EC official. Potential projects are evaluated using the CBA methodology and, after the final $\mathrm{PCI}$ list is adopted by the EC, confirmed projects receive EU funding. In addition, the $\mathrm{PCl}$ selection process has priority over the instruments of the ENTSO-E framework (Glachant 2017).

The TEN-E regulation significantly changes the institutional role of the TYNDP in European electricity policy. The TYNDP now constitutes the first stage of defining the need for future key grid development projects in Europe. Hence, participants in the TYNDP development process take into consideration the immediate connection with the $\mathrm{PCl}$ process, together with its significance for their respective interests (see Section 5).

To sum up, the TYNDP 2014 presents a significant upgrade from the 2012 edition in terms of both its scenario development methodology and its institutional significance. The developed scenarios are more detailed and diverse than those in the previous TYNDPs and cover a wider range of possible futures. All four scenarios developed in the TYNDP 2014 describe a decline in $\mathrm{CO}_{2}$ emissions, a rising share of electricity generated from renewable sources and, ultimately, achievement of the Roadmap 2050 goals. The report explicitly describes the share of projects that contribute to renewables integration and the mitigation of $\mathrm{CO}_{2}$ emissions at the European level. In addition, the TYNDP identifies around 100 projects of pan-European significance with a total investment need of $€ 150$ billion up to 2030 (ENTSO-E 2014a).

\footnotetext{
${ }^{9}$ The benefits for security of supply are described as being too high-level to be measured by the TYNDP project assessment methodology.

${ }^{10}$ North Seas offshore grid (NSOG); north-south electricity interconnections in western Europe (NSI West Electricity); northsouth electricity interconnections in central, eastern, and south-eastern Europe (NSI East Electricity); Baltic Energy Market Interconnection Plan in electricity (BEMIP Electricity).
} 

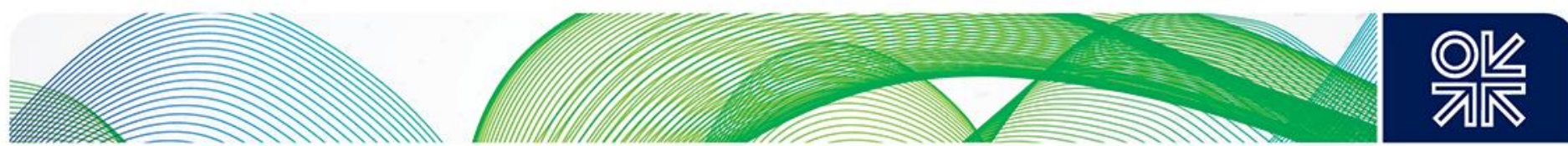

Ultimately, the TEN-E regulation ascribes to the TYNDP 2014 a more important role in the overall institutional setting of EU energy policy, as it is established as the exclusive basis for the identification of Projects of Common Interest.

\section{TYNDP 2016}

The 2016 edition of the TYNDP (see Figure 4.3) largely maintains and builds upon the scenario development storylines of the previous plan by developing four scenarios along the same two axes (pace of achievement of the Energy Roadmap 2050 targets and the degree of integration of the European electricity market). The scenarios are dubbed Slowest Progress, Constrained Progress, National Green Transition, and European Green Transition. The first and third scenarios are once again based on a bottom-up and the second and fourth on a top-down methodology. While they are generally consistent with the four scenarios developed in the TYNDP 2014, the 2016 scenarios are 'refocused on the EU 2030 goals' (ENTSO-E 2016, p. 42).

\section{Figure 4.3: TYNDP 2016 Visions for 2030}

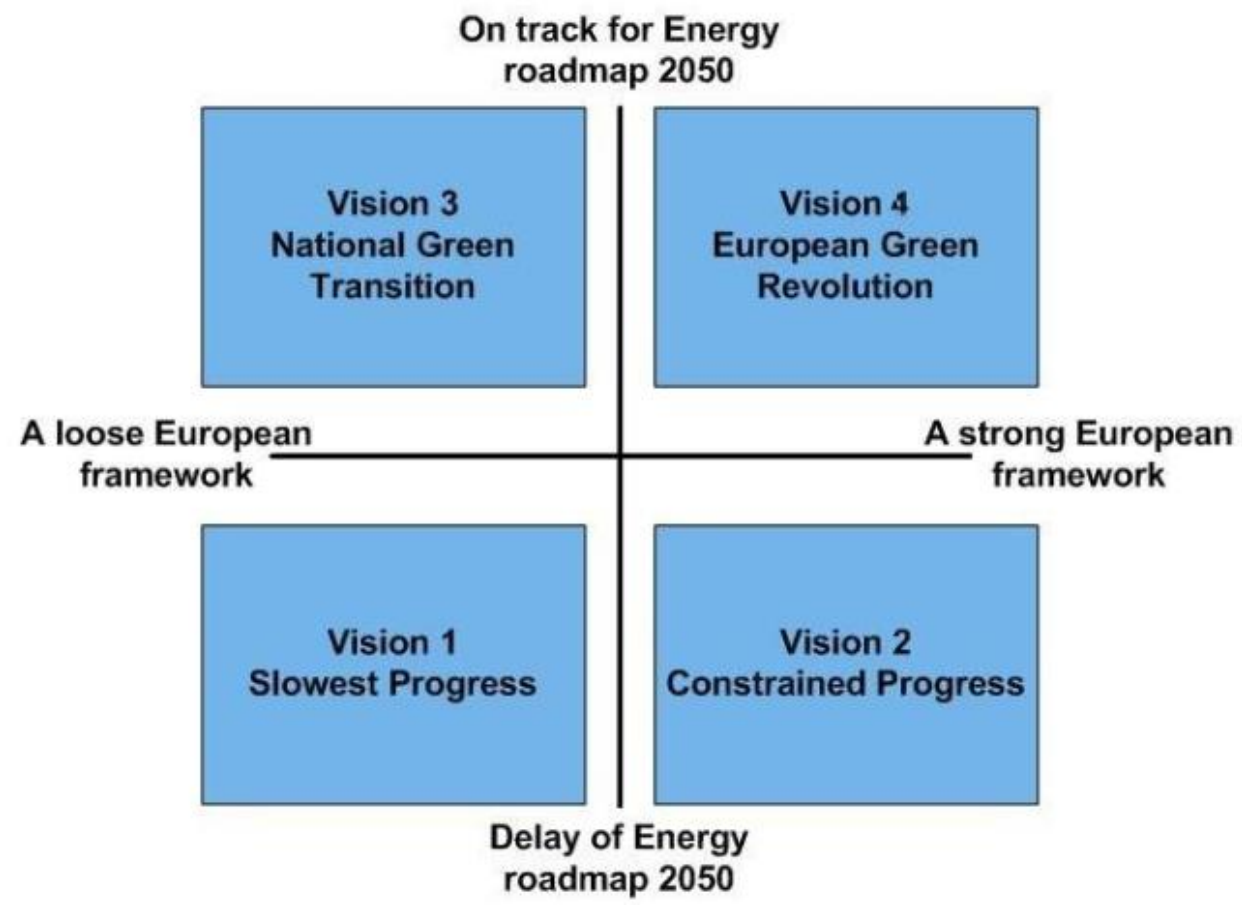

Source: ENTSO-E (2015, p. 10)

In addition, the TYNDP 2016 develops a fifth scenario for 2020. Based on stakeholder requests, the short-term scenario Expected Progress constitutes a forecast, and is understood as being the last point in the future before uncertainties in the development of the energy system increase (see Figure 4.4). It takes into consideration transmission and generation projects that have been determined by the time the TYNDP 2016 was published (ENTSO-E 2015). 

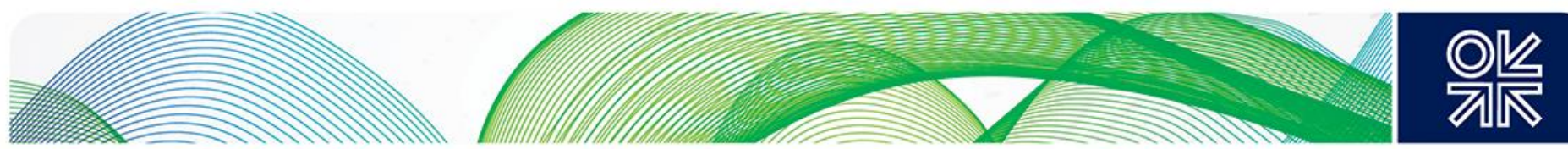

Figure 4.4: TYNDP 2016 scenario framework

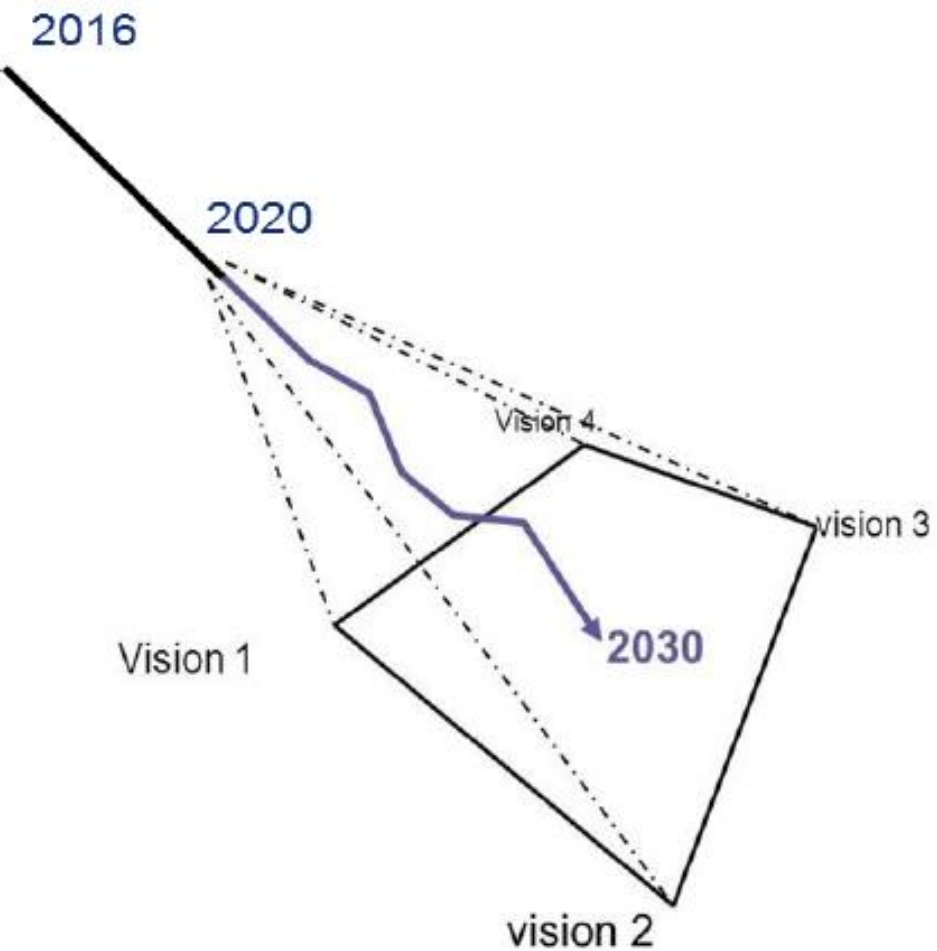

Source: ENTSO-E (2015, p. 9)

The four scenarios for 2030 all have in common a (varyingly) increasing share of electricity from renewable sources (45 per cent to 60 per cent of demand) and a decreasing $\mathrm{CO}_{2}$ intensity in the power sector ( -50 per cent to -80 per cent emissions reduction). In fact, all scenarios are aligned with the EU energy policy goals defined in the 2030 Energy Strategy, namely a 27 per cent share of renewable energy in European final consumption (this translates approximately to a 40 per cent share in power generation) and a 40 per cent reduction in overall $\mathrm{CO}_{2}$ emissions (European Council 2014; European Commission 2015b). ${ }^{11}$ Consequently, in comparison to the 2014 edition, the 2016 TYNDP's 'span of the four Visions is of course reduced, adapted to the Energy Union goals by a closer horizon' (ENTSOE 2016, p. 5). For instance, along the axis for 'pace of achievement of the Energy Roadmap 2050 targets', two scenarios are on track for achieving the Roadmap's goals, while the remaining two scenarios are aligned with the 2030 goals for renewables set in the 2030 Energy Strategy and the Energy Union Package (ENTSO-E 2015). Moreover, the projects included in the TYNDP 2016 guarantee the accomplishment of the 10 per cent interconnection capacity target for each member state by 2020, except for Spain (ENTSO-E 2016).

To sum up, the TYNDP 2016 largely retains the scenario design and methodology of the previous TYNDP and focuses more on stakeholder participation and feedback. However, the TYNDP 2016 scenarios are clearly aligned with, and focus on, the achievement of the EU energy policy goals for 2030 agreed on by the Council in October 2014. In turn, this results in the more narrow scope seen in the developed scenarios. With regard to infrastructure needs, the TYNDP 2016 ascribes $€ 150$ billion of investment in pan-European transmission projects, the majority linked to the integration of intermittent electricity from renewable sources (ENTSO-E 2016).

\footnotetext{
${ }^{11}$ On 14 June 2018, the EC, the European Parliament, and the Council reached an agreement on a binding renewable energy
} target for the EU for 2030 of 32\%, European Commission 2018c. 

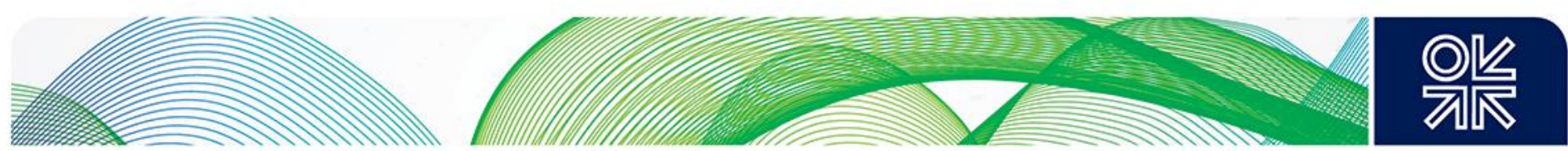

\section{TYNDP 2018}

The TYNDP 2018 is arguably the most comprehensive, complex, and detailed European network development plan developed. In general terms, the market modelling and climate database methodology for forecasting weather conditions have been improved and stakeholder engagement processes have evolved. ENTSO-E continues to emphasize the importance of participation and feedback. Moreover, the CBA methodology for assessing TYNDP projects has been advanced (now called CBA 2.0) and features the assessment of security of supply impact and storage projects (ENTSOE 2018b).

Nevertheless, two fundamental changes to the TYNDP 2018 stand out:

1. This edition of the network development plan has, for the first time, been conducted in cooperation between ENTSO-E and ENTSOG as a joint undertaking.

2. The scenario design was overhauled; it now covers future developments until 2040 and features eight scenarios for four different time horizons. Notably, the European Commission's EU Reference Scenario 2016 (EUCO Scenario) has been included as an external scenario for 2030.

The underlying rationale for the ENTSOs' joint development of the TYNDP 2018 is to take better advantage of the commonalities and overlaps of the future developments of the gas and electricity sectors and to acknowledge the input of a wider range of stakeholders. Both organizations pooled their technical expertise and scenario development experience in order to develop more comprehensive and robust scenarios for the European energy sector (ENTSOG and ENTSO-E 2018). However, the joint design of the process also resulted in a more complicated and lengthy development process for participants (Interview 8).

The second significant revision to the previous TYNDPs is a fundamental change in the TYNDP scenario design. The plan now describes two Best Estimate scenarios for the short (2020) and medium term (2025) respectively. These two scenarios follow a bottom-up logic and are based on the TSOs' estimates, and consider current national and European regulations. Their purpose is to map the development of the European energy system up to the point where uncertainties over possible future pathways become too great after 2025. For the year 2030, the TYNDP 2018 takes into consideration three scenarios and, for the first time, breaks with the outline of the scenario parameters (using two axes) as described in the previous TYNDPs. Instead, ENTSO-E developed two scenarios, Sustainable Transition and Distributed Generation that differ from one another with regard to a number of criteria such as: general economic conditions, growth of electric vehicle use, wind and solar generation capacity, and demand flexibility, among others. In addition, the EC's EUCO Scenario was included as a third pathway towards 2030 (See Figure 4.5).

The EUCO Scenario is based on the Commission's EU Reference Scenario 2016, published by the DGs for Energy, Climate Action, and Mobility and Transport in 2016. ${ }^{12}$ The aim of the Reference Scenario was to take into consideration current policies and market trends, and to project their impact on the development of the European energy system up to 2050. The scenario assumes the achievement of both the 2020 and 2030 EU energy policy goals (European Commission 2016b). Within the TYNDP 2018, the EUCO Scenario replaces the ENTSO-E internal Global Climate Action Scenario and covers the time horizon up to 2030. The incorporation of the EC's scenario into the TYNDP 2018 was initiated by the Commission (Interview 20) and evoked mixed reactions among stakeholders in the TYNDP process (Interviews 6, 12, 17, 18). In fact, ENTSO-E and ENTSOG also acknowledge that the different methodologies used in the externally and the internally developed scenarios negatively impact their compatibility (ENTSOG and ENTSO-E 2018, p. 9).

\footnotetext{
${ }^{12}$ The EU Reference Scenario 2016 was amended for the TYNDP but the EUCO Scenario uses the same data.
} 

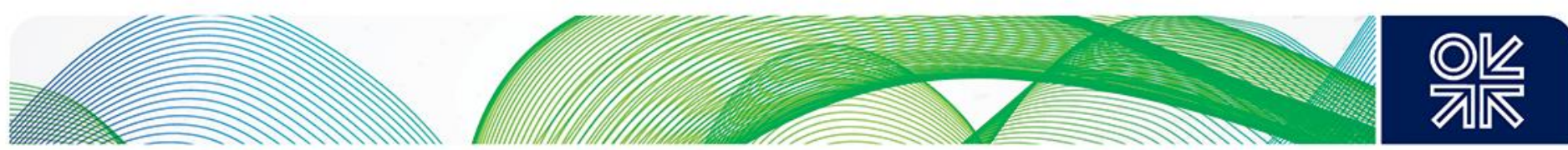

As for the scenarios covering 2040, the TYNDP 2018 continues the storylines of the two internally developed scenarios: Sustainable Transition and Distributed Generation and adds Global Climate Action (derived also from the Sustainable Transition 2030 storyline). The three scenarios are characterized by differences in a set of categories; however, they all show a pathway towards achieving EU targets for 2030 and $2050^{13}$ (ENTSO-E 2018d).

Figure 4.5: Overview of the TYNDP 2018 scenarios

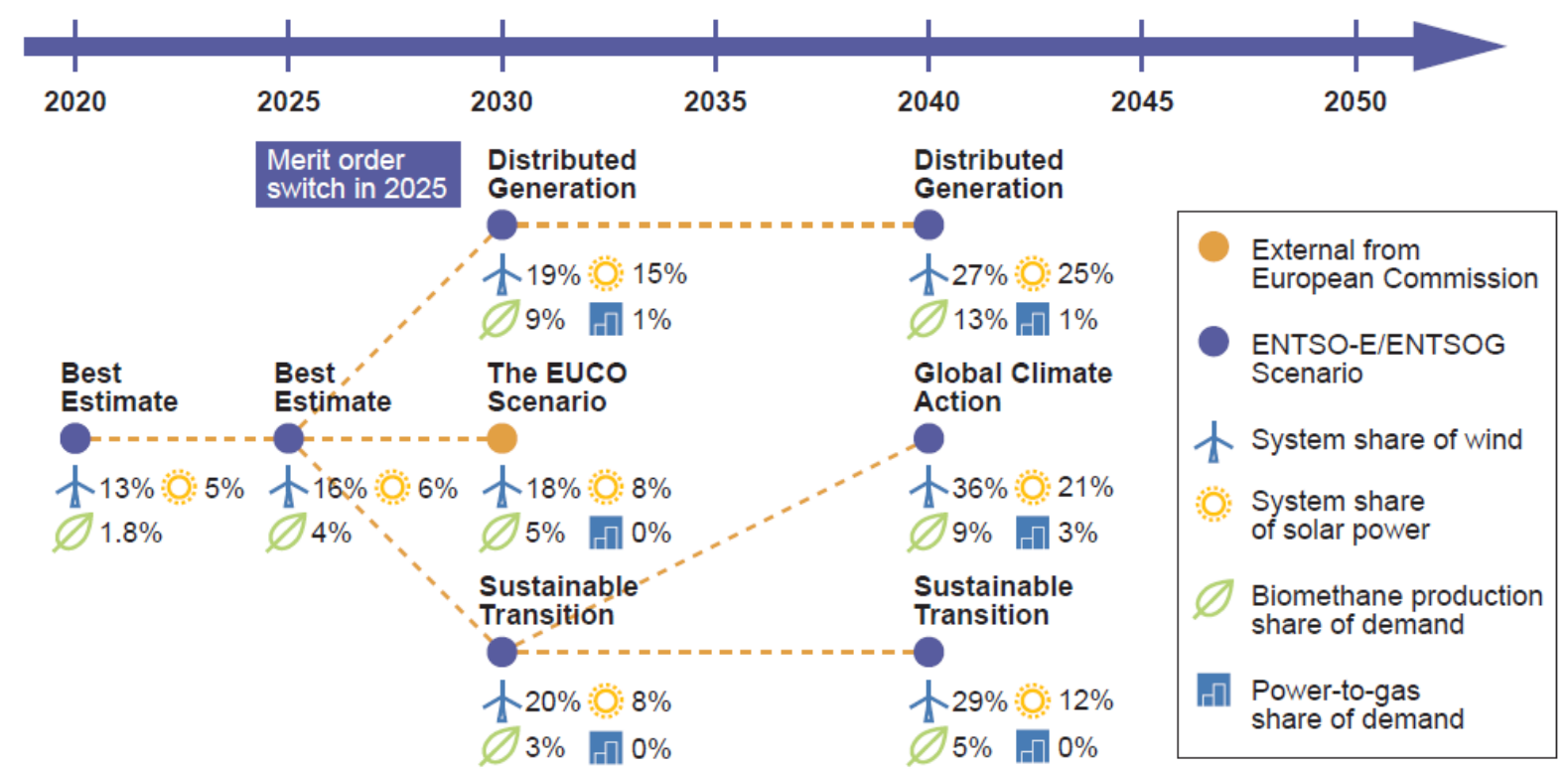

Source: ENTSOG and ENTSO-E (2018, p. 8)

In addition, the TYNDP 2018 directly refers to the proposals of the aforementioned Commission Expert Group on electricity interconnection targets. The plan assesses the criteria for greater interconnection investment (price differential between member states, regions, or bidding zones; transmission capacity in relation to peak load; transmission capacity in relation to installed renewable generation capacity) in the three 2030 scenarios, taking into account projects included in the TYNDP. As a result, it is determined by ENTSO-E that significant price differences still exist in all scenarios, signalling the need for additional interconnection capacity investments in addition to the project list included in the TYNDP 2018. Ultimately, in order to illustrate the need for grid investments, the 2018 edition of the TYNDP outlines the theoretical costs of non-investment in the European electricity grid infrastructure for 2030 and 2040, together with the negative impacts on security of supply, electricity prices, and the integration of electricity from renewable sources (ENTSO-E 2018d).

To sum up, the TYNDP 2018 features a substantially increased complexity with regard to both its development process and the scenarios. On the one hand, this is due to the cooperation with ENTSOG and the subsequent increase of involved stakeholders. On the other hand, the new scenario design and the multiple time horizons contribute to a more convoluted set of scenarios and possible future pathways. Nevertheless, all TYNDP 2018 scenarios are broadly in line with existing EU energy policy and with achieving the 2030 and 2050 targets. This is particularly visible due to the integration of the external EUCO Scenario, which is in fact an EU policy scenario.

\footnotetext{
${ }^{13}$ The scenario Sustainable Transition in 2040 lags slightly on its path towards achieving the 2050 goals.
} 

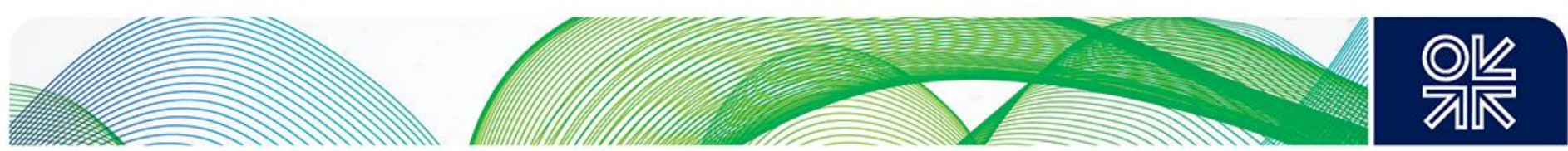

\section{Summary TYNDP and EU policy goals}

This section has explored the relationship between the TYNDPs and European energy policy. The document analysis has unearthed a policy congruence between the investigated TYNDPs and existing EU energy policy. To elaborate, this relationship manifests itself on two levels. First, the scenarios developed in the various TYNDPs widely assume the achievement of EU policy targets for 2020, 2030, and 2050. Moreover, they describe general future trends that are in line with European energy policies - such as an increasing share of renewables, reduction of $\mathrm{CO}_{2}$ emissions, and increased interconnection (resulting in extensive investments in cross-border transmission projects). ${ }^{14}$ This congruence is particularly visible where the TYNDP scenarios changed along the lines of new energy policies coming into place, for instance the TYNDP 2016 scenarios that refocused on the 2030 targets (ENTSO-E 2016). Therefore, the spectrum of possible future pathways is narrowed down. The second level of congruence relates to the evaluation of projects included in the TYNDPs. In addition to technical and economic aspects, the benefits of transmission and storage projects are assessed against their impact on EU policy goals, namely the integration of intermittent renewable electricity, the reduction of $\mathrm{CO}_{2}$ emissions, the completion of the internal market, and the contribution to security of supply.

As a result, all projects included in the TYNDP, and successfully assessed by the CBA methodology, are effectively contributing to the achievement of EU energy policy goals. This is further emphasized by the TYNDP's strong link to the PCI process, which is the Commission's central policy tool for triggering investment in key infrastructure that contributes to the energy policy goals.

The described policy congruence is indeed recognized by the different stakeholders involved in the TYNDP process. The development of scenarios is understood as a partially political process (Interview 10) in which political expectations, primarily articulated by the European Commission, have a substantial impact on the scenario outcome (Interviews 5, 7, 11). Effectively, the scenarios developed in the TYNDP are policy scenarios (Interview 17 ) which consider existing policy goals as a starting point (Interview 18) and are therefore politically constrained (Interviews 2, 12).

The following section investigates how the TYNDP's policy congruence is connected to its utilization by different stakeholders.

\section{Utilization of the TYNDP in the wider policymaking arena}

The TYNDP and its scenarios are utilized in the wider European energy policy in two ways. First, there is an interdependence between the national network development plans and the TYNDP. In particular, the national plans feed into the pan-European TYNDP. At the same time, TSOs and member states draw from the TYNDPs and its scenarios to further develop and adjust their national network development plans. In specific terms, most TSOs base their future cross-border projects primarily on the bottom-up scenarios of the TYNDP, which provides a wider European picture and indicates future developments in the neighbouring states and beyond (Interviews $1,3,4,8,17$ ). In fact, this aspect is also important for member states' national energy policies in terms of the integration of electricity from intermittent renewable sources and national system stability. Nevertheless, inconsistencies between the TYNDP and the national plans also exist; for instance the pursuit of national energy self-sufficiency in some member states versus the primacy of interconnectivity in the TYNDP (Interview 5). Ultimately, the TYNDP can be used by TSOs as a testing ground for projects that are not included in their binding national plan and which do not have the support of their respective NRA. In the case that one of these

\footnotetext{
${ }^{14}$ For example, substantially increased levels of European interconnectivity are foreseen in each policy scenario developed in the Commission's Energy Roadmap 2050, European Commission 2011.
} 

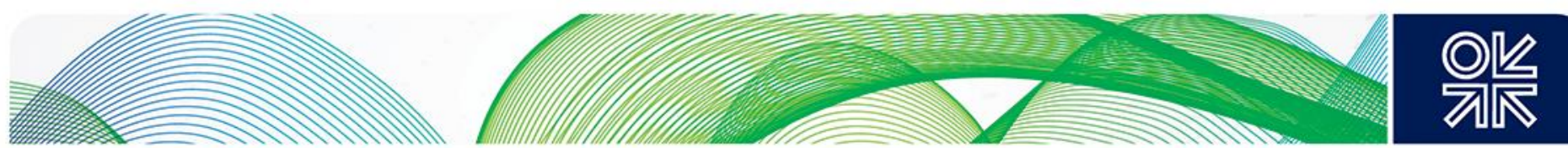

projects receives the $\mathrm{PCl}$ label, this could constitute a back door for TSOs to include a project in a national development plan (Interview 17).

The second and more significant utilization of the TYNDP and its scenarios in EU energy policy is connected to its relevance for the $\mathrm{PCl}$ selection process. As discussed above, the TYNDP presents the basis for identifying key European infrastructure projects, since future PCls need to be part of the previous TYNDP's project list (Crisan and Kuhn 2017). Since all the projects included in the TYNDP effectively contribute to EU energy policy goals, the selection of PCls is a logical and streamlined next step. Considering the TYNDP projects, those contributing the most to the European energy goals receive $\mathrm{PCl}$ status. $\mathrm{PCl}$ candidate projects are assessed using the same CBA as is applied in the TYNDP development process. As a consequence, all parts of the TYNDP development process are relevant for the $\mathrm{PCl}$ selection (see Figure 5.1).

\section{Figure 5.1: Interrelation TYNDP process and PCI projects}

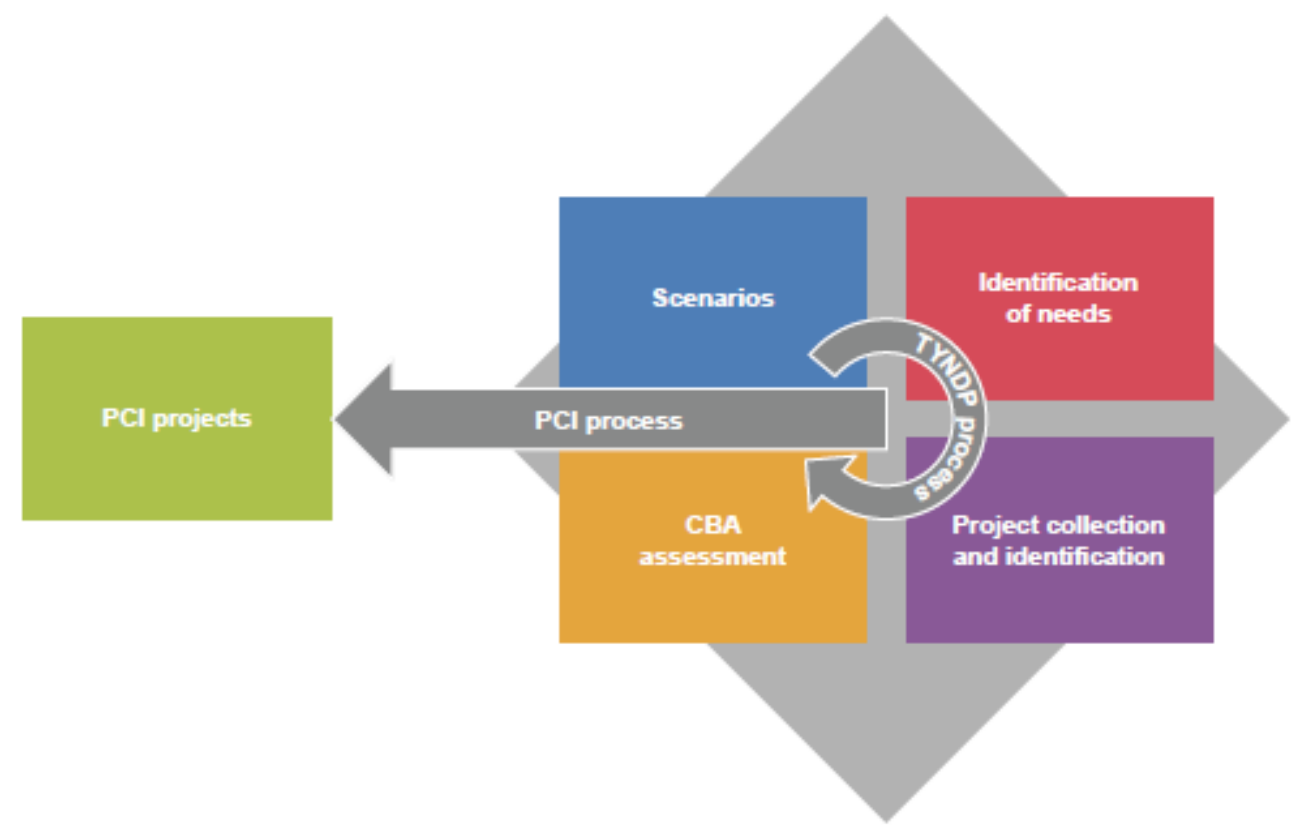

Source: ENTSO-E (2018d, p. 7)

The strong relevance for the $\mathrm{PCI}$ process determines how the TYNDP scenarios are utilized by key stakeholders and how and why these actors engage in the process.

As the central promoter of a European electricity system and the initiator and steward of the $\mathrm{PCl}$ process, the European Commission has a strong interest in the development of the TYNDP. The EC does not play a formal role in the TYNDP process. However, it has established the informal $P C l$ Cooperation Platform which brings together representatives from the ENTSO-E secretariat, ACER, and the Commission and it meets every four to six weeks. Through this platform, the Commission aims to receive first-hand information on TYNDP projects, voices its expectations with regard to the subsequent $\mathrm{PCl}$ process, and tries to guarantee the quality of the CBA. Ultimately, the EC attempts to influence the content and quality of the TYNDP and exercises a certain impact in this regard (Interviews 17, 19, 20). As described in Section 3.1, the PCls are the central instrument used to advance the hardware component of the European electricity market (Crisan and Kuhn 2017). Moreover, the purpose of PCls is also to directly contribute to the grid integration of intermittent electricity from renewable sources and to security of supply (European Commission 2018d). In other words, the PCI process links the TYNDP and its scenarios directly to the EU's energy policy goals. Therefore, it is crucial for the Commission to be informed about and to engage in the TYNDP development, in order to realize its energy policy goals. 

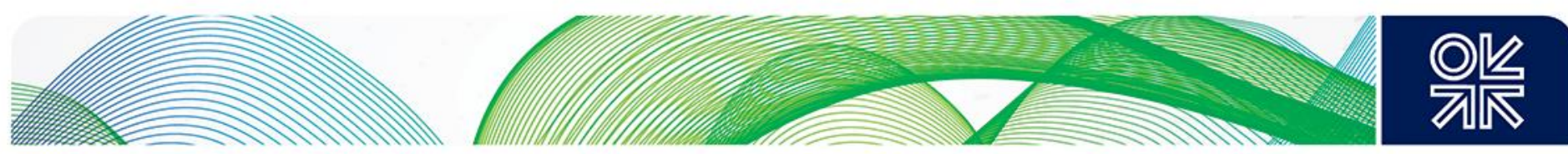

In fact, one TSO representative comprehends the TYNDP as an instrument to achieve the EU's renewable energy goals (Interview 6).

For TSOs as well, the link between the TYNDP and the PCI selection process is critical. While the TYNDP is a non-binding document, PCls are key European projects which have to be included in binding national network development plans. In addition, $\mathrm{PCl}$ projects can receive significant EU financial support. The Connecting Europe Facility (CEF) holds a total of $€ 5.35$ billion for PCls in the energy arena (European Commission 2018d). Typically, the CEF, via a grant, contributes 50 per cent to a PCl's total project costs. The largest such grant to date was the $€ 578$ million EU contribution to the France-Spain interconnection via the Bay of Biscay, which is currently under construction (European Commission 2018b). In addition, project promoters of PCls can apply for the European Investment Bank's (EIB) European Fund for Strategic Investments (EFSI) scheme. The EFSI finances up to 50 per cent of project costs and provides preferential loans. ${ }^{15}$ In particular, the fund's central objective is to trigger additional financing from private investors encouraged by the EIB's approval for the project (Interview 15). The CEF and EFSI can be combined and cover a project's feasibility studies, planning, and construction. The EU financial support instruments described give TSOs a very strong incentive to focus on getting their projects onto the $\mathrm{PCl}$ list, in order secure the additional funding and preferential financing (Interview 10). Moreover, the PCl status is connected to an accelerated permitting process, a streamlined environmental impact assessment, and simpler regulations (European Commission 2018d). These measures can potentially shorten a transmission project's permitting procedure from an average of 10 years to three and a half years, a political and financial benefit for TSOs (European Commission 2017a). From a business perspective, a project labelled as a $\mathrm{PCl}$ is an enormously advantageous investment opportunity for a TSO.

In addition, the $\mathrm{PCl}$ status enables project promoters to invoke the overruling of public interest, potentially stifling local environmental concerns and further streamlining the permitting process (see below). Ultimately, the $\mathrm{PCI}$ label is linked to a certain prestige for the promoting TSO vis-à-vis private investors and the respective NRA and national government (Interviews 9, 10, 13, 15). Hence, in general during the TYNDP development, TSOs have strong incentives for their projects to be part of the project list to qualify for the subsequent $\mathrm{PCl}$ selection process. Environmental protection interest groups are also aware of the TYNDP's significance for the PCI selection. For instance, due to the streamlined permission process and the possibility of overruling public interest, $\mathrm{PCl}$ projects can be permitted to have a bigger environmental impact than regular electricity infrastructure projects. ${ }^{16}$ Moreover, once the $\mathrm{PCl}$ status is granted to a project, opposing its construction becomes more challenging due to its certified relevance for the European energy system. As a result, environmental groups are closely monitoring the TYNDP process and trying to influence its project list in view of the subsequent PCI selection (Interviews 13,14).

To summarize, the utilization of the TYNDP and its scenarios revolves around the interconnection with national network development plans and the strong link to the PCls. In particular, this section has shown that the TYNDP's importance for EU energy policy is based in its close connection to the PCl selection process. Consequently, the European Commission, as the central promoter of a European electricity policy, seeks to utilize the TYNDP to facilitate the achievement of the respective EU policy goals through key infrastructure investments.

\footnotetext{
${ }^{15}$ For the Italy-France electricity interconnector, for example, the EFSI provided a $€ 130$ million loan over a term of 22 years with a fixed interest rate of $1.64 \%$, EIB 2017.

${ }^{16}$ For example, the hydro-pumped electricity storage project in Kaunertal, Austria (PCI no. 2.18) would have negative effects on a Natura 2000 protected area (Interview 13).
} 

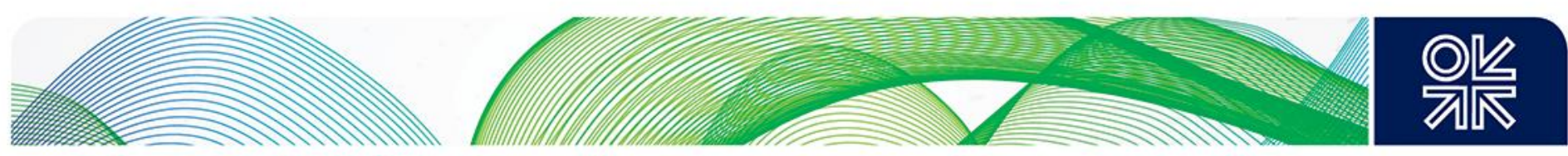

\section{Results}

Section 4 has revealed, in the TYNDP scenarios, a significant congruence with EU energy policy goals. In addition, the strong link between the TYNDP and the PCI selection process has been illustrated. The analysis has shown that these two aspects are closely connected. To elaborate, the common critical denominator for all three pillars of European electricity policy - a competitive market, the mitigation of climate change, and a secure supply - is the construction of cross-border transmission lines (see Section 3). The PCls are the European Commission's central policy tool to facilitate investments in these key infrastructure projects. Finally, the function of ENTSO-E's TYNDP is to bridge the EU policy goals and the PCls. In particular, the projects included in the TYNDP effectively all contribute to EU goals and, as a consequence, PCls are selected from the TYNDP project list using the same costbenefit analysis.

The analysis gives rise to questions for both the TYNDP's ability to identify future challenges in the European electricity system and for the effectiveness of the $\mathrm{PCl}$ selection process in allocating infrastructure investments.

The policy congruence and strong link with the $\mathrm{PCl}$ selection process results in the TYNDP being exclusively focused on the hardware component of the future European electricity system. This is reinforced by the setting of the TYNDP process. To illustrate, the key actors in the development are TSOs who are naturally keen on constructing more infrastructure and can benefit from the incentives attached to the $\mathrm{PCl}$ status. At the same time, regulatory and market aspects represented through ACER have a very limited role in the TYNDP, as the agency only gives a non-binding opinion at the very end of the development process (Interviews 17, 18).

The unilateral focus on infrastructure raises the question of the TYNDP's effectiveness in achieving its objectives. On the one hand, the plan identifies future challenges and infrastructure investment needs as part of its self-proclaimed goals (ENTSO-E 2018d). On the other hand, the TYNDP does not acknowledge the underlying, and currently inadequate, European electricity market design. For instance, the current TYNDP's CBA methodology does not consider the impact of national capacity markets. At the same time, the capability of the current European electricity market design to incentivize dispatchable generation is questioned in the TYNDP itself (ENTSO-E 2018d). This limits the TYNDP's effectiveness as a planning tool, since the hardware of an interconnected electricity system is closely linked to its software component. To elaborate, the software and regulation of the future European electricity system will be different from today's design - it is possible to imagine a Europe-wide capacity mechanism or harmonized support schemes for renewable energy. However, these potential software developments are not reflected in the TYNDP. Nevertheless, software reforms and improved regulations would strongly affect the infrastructure that is required in any future European electricity system. To that end, the TYNDP in its current form fails to provide holistic pictures of a range of possible future electricity system architectures, as the decisive market designs and regulatory developments are not considered. As a direct consequence, the current TYNDP scenarios identify future challenges for the European electricity system to only a limited extent.

The described issue associated with the TYNDP leads to the question of whether the PCI selection process, which draws directly from the TYNDP's project list and cost-benefit analysis, is capable of allocating the necessary infrastructure investments effectively. Principally a political process championed by the European Commission, the $\mathrm{PCl}$ selection process imposes infrastructure projects on the European electricity market which, in its current form, is effectively broken (see Section 3.1). For example, the considerable financial support provided by the EU in form of the CEF illustrates that the present market design is flawed. In fact, in its own capacity the electricity market does not provide the necessary economic incentives for TSOs to invest in these key infrastructure projects. To that end, the $\mathrm{PCls}$ potentially promote politically motivated outcomes and may underestimate economic or technological aspects. Similar to the TYNDP, this points to a problem in which the underlying current 

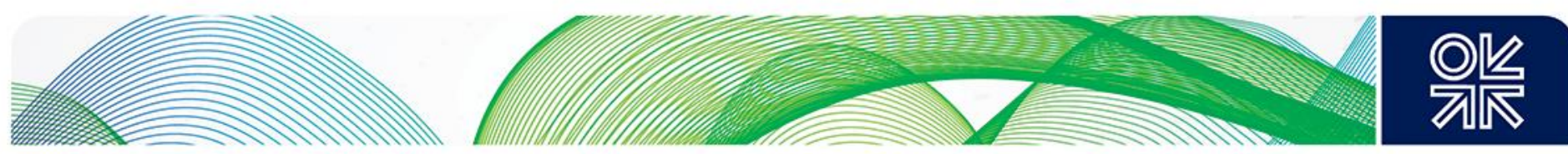

and future market structures and regulations are not considered. Consequently, potentially deficient investment decisions are being taken.

A potential solution to the stated problems is two-fold. First, a fundamental reform of the European electricity market design is needed. An effective market architecture would need to factor in capacity mechanisms and renewable support schemes, in order to provide the correct price signals and incentives for infrastructure investments. With a working market mechanism in place, the economic incentives to invest in PCls could be strengthened. As a result, key interconnections would be located where the economic need is greatest, for instance where substantial cross-border price differences or congestions occur. In turn, this would provide a business case for TSOs to invest in key cross-border infrastructure projects and make the massive EU funding, in form of the CEF, obsolete. At the same time, both the preferential loans provided by the EIB and the streamlined permitting process currently granted to PCls should be retained. On the one hand, this would encourage additional private investment and help TSOs to accelerate the investment decision process. On the other hand, a swift roll-out of these key projects would be guaranteed and their European significance would be emphasized. With regard to the TYNDP, the plan would benefit from a functioning electricity market template, as the software component of the future electricity system needs to be considered in its scenarios. In addition, the assessment of current and future infrastructure projects could be based on a functioning market design that is already in place.

Second, and complementary to the first measure, a pan-European regulation of the electricity system is necessary. By strengthening the role of ACER and developing the agency into a European regulator, measures such as harmonized renewables support schemes and a European capacity mechanism can be achieved. Therefore, the agency would need to be equipped with more far-reaching competences to be capable of devising binding pan-European electricity market regulations. ACER could then act as an arbiter and coordinator, to ensure that crucial infrastructure investments like the PCls are allocated effectively. ${ }^{17} \mathrm{~A}$ stronger role for ACER would then also be reflected in the TYNDP. By assuming a more proactive role and engaging at an earlier stage of the development process, ACER would ensure that the software component of the future electricity system is incorporated into the TYNDP process. For instance, the agency could pool and reconcile the positions of NRAs in order to account for the different possible electricity market designs and future regulations in the TYNDP scenarios.

The combination of the two proposed measures would significantly improve the effectiveness of the combined TYNDP and PCI processes by accounting for the software component in the future electricity system and by allocating key infrastructure projects on the basis of economic and technical requirements.

Ultimately, in terms of the TYNDP scenario design, the analysis has illustrated that the TYNDP's policy congruence confines the developed scenarios. This can have a negative impact on the ability of these scenarios to identify essential uncertainties in the future development of the energy system. As a consequence, the TYNDP's effectiveness as a strategic planning tool is further limited. In order to determine these uncertainties and the connected challenges more effectively, two different improvements to the current TYNDP design are conceivable. First, the range of the developed scenarios could be extended so that, for example, disruptive technologies and their impact on the electricity infrastructure can be accounted for (Interview 16). This could include, but is not limited to, the large-scale application of fracking, a breakthrough in carbon capture and storage/usage technologies (CCS/CCU), or peer-to-peer electricity trading. The second improvement would entail a stronger focus on the most critical system challenges associated with the envisioned policy goals. For example, it would be possible to ask: how would a renewables share in electricity generation of close to 100 per cent in 2050 (European Commission 2011) impact the operation of the current system? At what pace

\footnotetext{
${ }^{17}$ The European Commission's proposal to strengthen the role of ACER, articulated in the Clean Energy Package, is a first step into the proposed direction.
} 

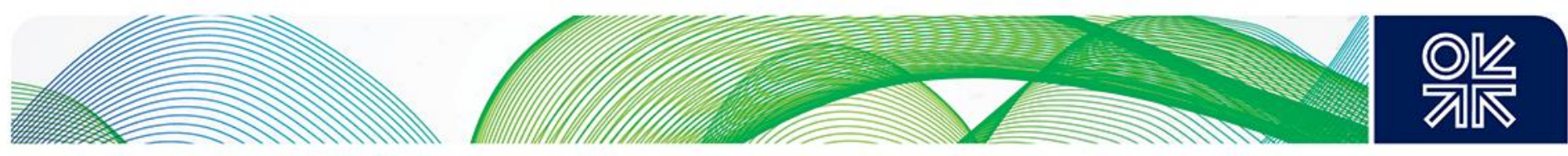

would renewables capacity need to be added? And, what would that mean for the operation of the system in 10, 15, and 20 years? By answering these and similar questions within the TYNDP framework, a better identification of the most significant future challenges would be possible and investment needs could be devised accordingly, in order to meet the future policy goals.

\section{Conclusion}

The investigation has illustrated that although the development of the TYNDP is a technical process driven by ENTSO-E and TSOs, the developed scenarios and their implications for European network development have to be understood in a wider political context. To elaborate, the scenarios across the analysed TYNDPs are congruent with existing EU policy goals. In other words, the range of scenario assumptions is confined by political expectations about the future development of the European energy sector. This is particularly visible in the scenarios' assumptions on the future share of electricity from renewable sources, reduction of $\mathrm{CO}_{2}$ emissions, and increased interconnectivity in Europe. In addition, future electricity transmission and storage projects in the TYNDP are assessed for their contribution to EU policy goals.

The outlined policy congruence is closely connected to the way in which policymakers and stakeholders utilize the TYNDP. In this regard, the TYNDP's relevance for the PCl selection process stands out, as it constitutes the first step in the process of identifying key pan-European electricity transmission and storage projects. As a consequence, the European Commission is particularly attentive and engaged in the TYNDP development process. Having in mind the subsequent $\mathrm{PCl}$ selection process, the EC comprehends the TYNDP as being a first step in facilitating the realization of EU energy policy goals through infrastructure investments. Moreover, environmental protection groups and TSOs are also aware of the TYNDP's pertinence for the PCl process and the resulting impact on the financing, permitting, and prestige of future infrastructure projects. The second consequence of the described policy congruence is an exclusive focus on the hardware component of the future European electricity system within the TYNDP and PCI framework. As the hardware and software aspects of any given electricity system are closely interlinked and will impact each other, an effective modelling of plausible future European electricity systems is not feasible by focusing solely on infrastructure projects. To elaborate, an evolution of European electricity market design - for instance the integration of harmonized renewables support schemes or a European capacity mechanism - is not considered in the current TYNDP architecture. Nevertheless, these software reforms would have a significant impact on the infrastructure system requirements. As a consequence, the TYNDP fails to provide a holistic picture of the future European electricity system and gives only a limited indication of the related future challenges.

The analysis has ascertained a similar issue for the PCl process. The PCls are key infrastructure projects that are being imposed on a European electricity market that is highly ineffective in providing the correct price signals and encouraging investment. Since the underlying market design is not capable of giving economic incentives for TSOs to invest in these projects, strong EU financial support is provided. Hence, the $\mathrm{PCl}$ selection is a politically motivated process championed by the Commission, which risks underestimating economic and technological aspects since the fundamental market failures are not addressed.

In order to address these issues, this research suggests two measures. First, a fundamental reform of the European electricity market design is needed. An effective market architecture would need to factor in capacity mechanisms and renewables support schemes, in order to provide correct price signals and incentives for infrastructure investments. This would allow for a more effective allocation of key infrastructure investments. In addition, the TYNDP process would benefit from a functioning electricity market template, as the software component of the future electricity system needs to be considered in its scenarios. This, in turn, could be achieved through a more active and earlier involvement of ACER, 

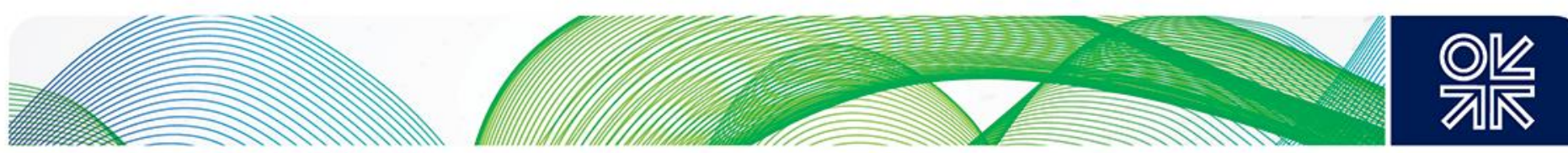

which would enable the inclusion of different plausible future market designs and European regulatory aspects. This leads up to the second measure, namely the stronger regulation of the electricity system at EU level by transforming ACER into a European regulator. Outfitted with appropriate competences, the agency would be capable of introducing, among other measures, European capacity mechanisms and harmonized renewables support schemes, thereby contributing to the functioning of the European electricity market. In addition, ACER could act as an arbiter, acting to guard key infrastructure investments, on the basis of system needs and facilitated by economic incentives. Ultimately, a stronger institutional position for ACER would go hand in hand with its improved engagement in the TYNDP process and facilitate the integration of the software component into the scenarios. In turn, this would improve the TYNDP's effectiveness as a strategic planning tool for Europe's future electricity system. 

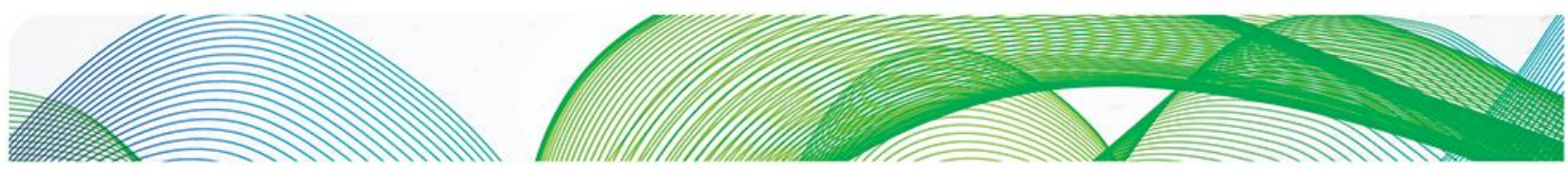

\section{이존}

\section{Conducted interviews}

Interview 1, TSO, November 2016

Interview 2, TSO, December 2016

Interview 3, TSO, January 2017

Interview 4, TSO, January 2017

Interview 5, TSO, January 2017

Interview 6, TSO, January 2017

Interview 7, TSO, March 2017

Interview 8, TSO, March 2017

Interview 9, TSO, April 2017

Interview 10, TSO, May 2017

Interview 11, TSO, May 2017

Interview 12, Environmental Protection Association, September 2017

Interview 13, Environmental Protection Association, October 2017

Interview 14, Environmental Protection Association, October 2017

Interview 15, EIB, November 2017

Interview 16, Electrical Equipment Manufacturer Association, February 2018

Interview 17, ACER, May 2018

Interview 18, NRA, September 2018

Interview 19, EC DG Energy, September 2018

Interview 20, EC DG Energy, October 2018 

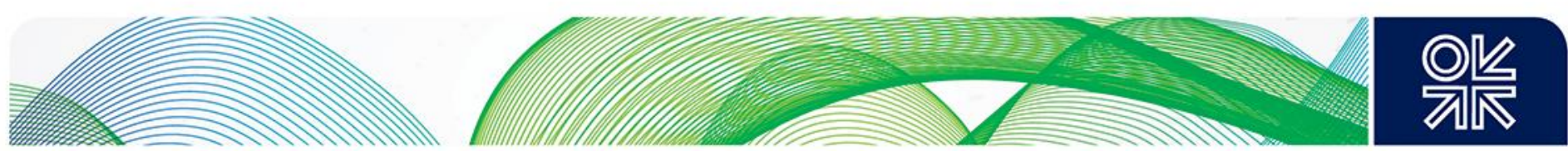

\section{Bibliography}

Biesenbender, Sophie (2015): 'The EU's Energy Policy Agenda: Directions and Developments'. In Jale Tosun, Sophie Biesenbender, Kai Schulze (Eds.): Energy Policy Making in the EU. Building the Agenda. London: Springer London (Lecture Notes in Energy, 28), pp. 21-40.

Buchan, David (2009): Energy and climate change: Europe at the cross roads. Oxford: Oxford University Press.

Buchan, David (2015): 'Energy Policy: Sharp Challenges and Rising Ambitions'. In Helen Wallace, Mark A. Pollack, Alasdair R. Young (Eds.): Policy-making in the European Union. 7th edition. Oxford: Oxford University Press (The new European Union series), pp. 344-66.

Buchan, David; Keay, Malcolm (2015): Europe's long energy journey. Towards an energy union?. First edition. Oxford: Oxford University Press for the Oxford Institute of Energy Studies.

Buchan, David; Keay, Malcolm (2016): ‘EU energy policy - 4th time lucky?'. Oxford Energy Comment. Oxford Institute for Energy Studies. Oxford. Available online at https://www.oxfordenergy.org/wpcms/wp-content/uploads/2016/12/EU-energy-policy-4th-timelucky.pdf, checked on 10/9/2018.

Commission Expert Group on electricity interconnection targets (2017): 'Towards a sustainable and integrated Europe'. Available online at

https://ec.europa.eu/energy/sites/ener/files/documents/report_of_the_commission_expert_group_on_ electricity_interconnection_targets.pdf, checked on 21/9/2018.

Council of the European Union (2005): Presidency Conclusions of the 15/16 December 2005 Brussels European Council. 15914/1/05.

Council of the European Union (2007): Presidency Conclusion of the 8/9 March 2007 Brussels European Council. 7224/1/07.

Crisan, Adina; Kuhn, Maximilian (2017): 'The Energy Network: Infrastructure as the Hardware of the Energy Union'. In Svein S. Andersen, Andreas Goldthau, Nick Sitter (Eds.): Energy Union. Europe's new liberal mercantilism? London: Palgrave Macmillan (International political economy series), pp. 165-82.

Domanico, Fabio (2007): 'Concentration in the European electricity industry: The internal market as solution?'. In Energy Policy 35 (10), pp. 5064-76.

EIB (2017): 'Terna: EIB lends EUR 130 million for "Italy-France" interconnector'. Press Release. Available online at http://www.eib.org/en/infocentre/press/releases/all/2017/2017-211-terna-eib-lendseur-130-million-for-italy-france-interconnector.htm?f=search\&media=search, checked on 15/11/2018.

Eikeland, Peer Ove (2011): 'The Third Internal Energy Market Package: New Power Relations among Member States, EU Institutions and Non-state Actors?'. In Journal of Common Market Studies 49 (2), pp. 243-63.

Eising, Rainer; Jabko, Nicolas (2001): 'Moving Targets. National Interests and Electricity Liberalization in the European Union'. In Comparative Political Studies 34 (7), pp. 742-67.

ENTSO-E (2010): 'Ten-Year Network Development Plan 2010-2020'. Brussels. Available online at https://docstore.entsoe.eu/fileadmin/user_upload/_library/SDC/TYNDP/TYNDP-final_document.pdf, checked on 3/10/2018.

ENTSO-E (2012a): 'Scenario Outlook and Adequacy Forecast 2012-2030'. Brussels. Available online at https://www.entsoe.eu/fileadmin/user_upload/_library/SDC/SOAF/120705_SOAF2012_final.pdf, checked on 28/1/2016. 

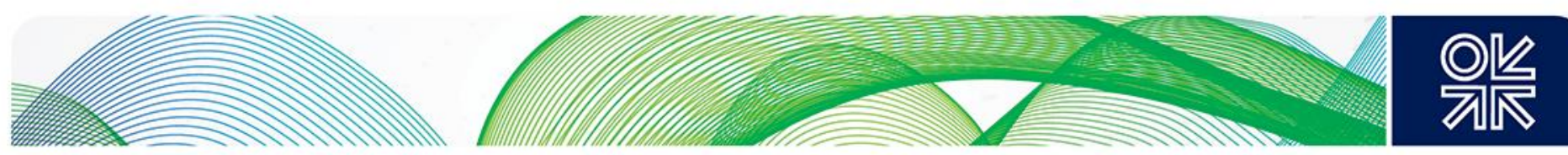

ENTSO-E (2012b): 'Ten-Year Network Development Plan 2012'. Brussels. Available online at https://docstore.entsoe.eu/fileadmin/user_upload/_library/SDC/TYNDP/2012/TYNDP_2012_report.pdf , checked on 8/10/2018.

ENTSO-E (2014a): '10-Year Network Development Plan 2014'. Brussels. Available online at https://docstore.entsoe.eu/major-projects/ten-year-network-development-plan/tyndp2014/Documents/TYNDP\%202014_FINAL.pdf, checked on 3/10/2018.

ENTSO-E (2014b): 'Scenario Outlook and Adequacy Forecast 2014-2030'. Brussels. Available online at https://docstore.entsoe.eu/Documents/TYNDP\%20documents/TYNDP\%202014/140602_SOAF\%202 014-2030.pdf, checked on 11/10/2018.

ENTSO-E (2015): 'TYNDP 2016 Scenario Development Report'. Final after public consultation.

Brussels. Available online at

https://docstore.entsoe.eu/Documents/TYNDP\%20documents/TYNDP\%202016/rgips/TYNDP2016\%2 0Scenario\%20Development\%20Report\%20-\%20Final.pdf, checked on 3/10/2018.

ENTSO-E (2016): 'Ten-Year Network Development Plan 2016'. Executive Report. Brussels. Available online at https://tyndp.entsoe.eu/projects/2016-12-20-1600-exec-report.pdf, checked on 2210//2018.

ENTSO-E (2018a): 'ENTSO-E Member Companies'. Available online at https://www.entsoe.eu/about/inside-entsoe/members/, checked on 29/9/2018.

ENTSO-E (2018b): 'Improvements of TYNDP 2018'. Available online at https://tyndp.entsoe.eu/Documents/TYNDP\%20documents/TYNDP2018/consultation/Communication/ ENTSO_TYNDP_2018_Improvements.pdf, checked on 24/10/2018.

ENTSO-E (2018c): 'System protection behavior and settings during system disturbances'. Review Report. Available online at https://docstore.entsoe.eu/Documents/SOC\%20documents/Regional_Groups_Continental_Europe/20 18/180606_SOC_TOP_07.2_D.2_System_protection_behaviour\%20and_settings_during_system_dis turbances.pdf, checked on 27/9/2018.

ENTSO-E (2018d): 'Connecting Europe: Electricity: 2025-2030-2040'. TYNDP 2018 Executive Report. Available online at https://tyndp.entsoe.eu/Documents/TYNDP\%20documents/TYNDP2018/consultation/Main\%20Report /TYNDP2018_Executive\%20Report.pdf, checked on 26/10/2018.

ENTSOG; ENTSO-E (2018): 'Scenario Report'. TYNDP 2018 Available online at https://docstore.entsoe.eu/Documents/TYNDP\%20documents/TYNDP2018/Scenario_Report_2018_F inal.pdf, checked on 24/10/2018.

European Commission (1997): 'Energy for the Future: Renewable Sources of Energy'. COM(97) 599 final.

European Commission (2007): 'An Energy Policy for Europe'. COM(2007) 1 final.

European Commission (2008): 2020 by 2020. 'Europe's climate change opportunity' (the 'Climate and Energy Package'). COM(2008) 30 final. 3

European Commission (2010): 'Energy 2020. A strategy for competitive, sustainable and secure energy'. $\operatorname{COM}(2010) 639$ final.

European Commission (2011): ‘Energy Roadmap 2050’. COM (2011)885 final.

European Commission (2014): 'A policy framework for climate and energy in the period from 2020 to 2030'. COM (2014) 15 final. 

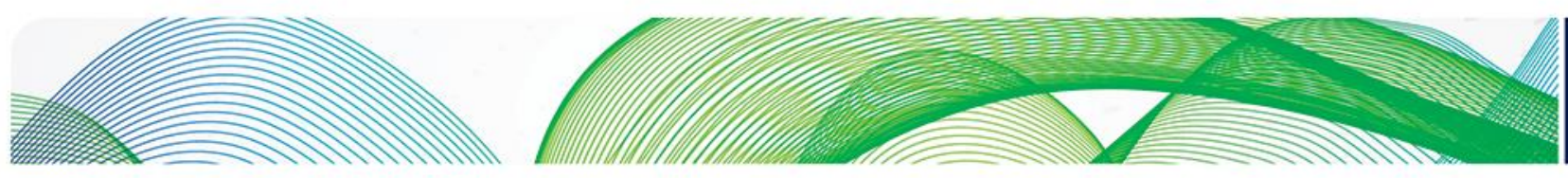

European Commission (2015a): 'Achieving the 10\% electricity interconnection target. Making Europe's electricity grid fit for 2020'. COM(2015) 82 final.

European Commission (2015b): 'Energy Union Package. A Framework Strategy for a Resilient Energy Union with a Forward-Looking Climate Change Policy'. $\operatorname{COM(2015)~} 80$ final.

European Commission (2015c): 'Investment perspectives in electricity markets'. Luxembourg (European economy Institutional paper, 003).

European Commission (2016a): 'Clean Energy for all Europeans'. COM(2016) 860 final.

European Commission (2016b): 'EU Reference Scenario 2016. Energy, transport and GHG emissions: Trends to 2050'. Luxembourg: EU Publications Office.

European Commission (2016c): 'Internal market for electricity'. COM (2016) 861 final.

European Commission (2017a): 'Commission delegated Regulation amending Regulation (EU) No $347 / 2013$ of the European Parliament and of the Council as regards the Union list of projects of common interest'. SWD(2017) 425 final. Available online at

https://ec.europa.eu/energy/sites/ener/files/documents/swd_accompanying_pci_list_final_2017_en.pd f, checked on $15 / 11 / 2018$.

European Commission (2017b): 'Communication on strengthening Europe's energy networks'. $\operatorname{COM}(2017) 718$ final.

European Commission (2018a): 'Commission Delegated Regulation (EU) 2018/540 of 23 November 2017 amending Regulation (EU) No 347/2013 of the European Parliament and of the Council as regards the Union list of projects of common interest'. In Official Journal of the European Union L 90, pp. 38-58.

European Commission (2018b): 'Connecting Europe Facility Energy. Supported actions - May 2018'. Brussels. Available online at https://ec.europa.eu/inea/sites/inea/files/cefpub/cef_energy_brochure_2018_web.pdf, checked on $15 / 11 / 2018$.

European Commission (2018c): 'Europe leads the global clean energy transition: Commission welcomes ambitious agreement on further renewable energy development in the EU'. Press Release, 14 June 2018. Available online at http://europa.eu/rapid/press-release_STATEMENT-184155_en.htm, checked on 23/10/2018.

European Commission (2018d): 'Projects of Common Interest'. Available online at https://ec.europa.eu/energy/en/topics/infrastructure/projects-common-interest, checked on $31 / 10 / 2018$.

European Council (2013): 'Conclusion of the 22 May 2013 European Council'. EUCO 75/1/13.

European Council (2014): 'Conclusion of the 23/24 October 2014 European Council'. EUCO 169/14. 4.

European Council (2015): 'Conclusions of the 19/20 March 2015 European Council'. EUCO 11/15.

European Parliament (2015): 'European Parliament resolution of 15 December 2015 on Towards a European Energy Union'. 2015/2113(INI).

European Parliament and Council of the European Union (2009a): 'Directive 2009/28/EC of the European Parliament and the Council of 23 April 2009 on the promotion of the use of energy from renewable sources and amending and subsequently repealing Directives 2001/77/EC and 2003/30/EC'. In Official Journal of the European Union L 140, pp. 16-62. (The 'Renewable Energy Directive'.) 

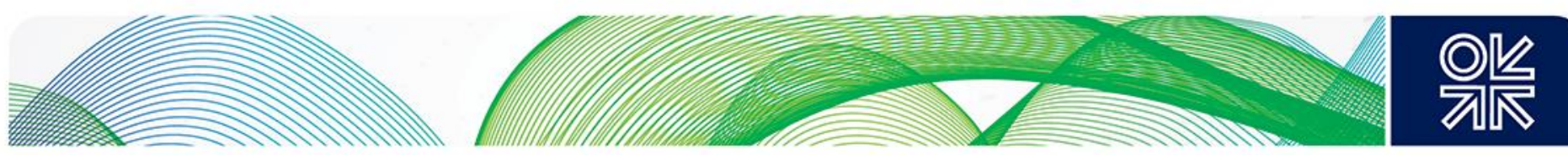

European Parliament and Council of the European Union (2009b): 'Regulation (EC) No 714/2009 of the European Parliament and of the Council of 13 July 2009 on conditions for access to the network for cross-border exchanges in electricity and repealing Regulation (EC) No 1228/2003'. In Official Journal of the European Union L 211, pp. 15-35.

European Parliament and Council of the European Union (2013): 'Regulation (EU) No 347/2013 of the European Parliament and of the Council of 17 April 2013 on guidelines for trans-European energy infrastructure and repealing Decision No 1364/2006/EC and amending Regulations (EC) No 713/2009, (EC) No 714/2009 and (EC) No 715/2009'. In Official Journal of the European Union L 115, pp. 39-75.

Fischer, Severin (2017): 'Global energy security and EU energy policy'. In Rafael Leal-Arcas, Jan Wouters (Eds.): Research handbook on EU energy law and policy. Cheltenham, UK: Edward Elgar Publishing (Research handbooks in European law), pp. 150-64.

Franza, Luca; van der Linde, Coby (2017): 'Geopolitics and the Foreign Policy Dimension of EU energy security'. In Svein S. Andersen, Andreas Goldthau, Nick Sitter (Eds.): Energy Union. Europe's new liberal mercantilism? London: Palgrave Macmillan (International political economy series), pp. 85-97.

Glachant, Jean-Michel (2016): 'Tacking stock of the EU "Power Target Model”... and steering its future course'. In Energy Policy 96, pp. 673-9.

Glachant, Jean-Michel (2017): 'Twenty years to address electricity market and system seams issues in the European Union: Why? Why not?' In EUI Working Papers RSCAS 2017/50. Available online at http://cadmus.eui.eu/bitstream/handle/1814/48048/RSCAS_2017_50.pdf?sequence=1\&isAllowed=y, checked on 18/10/2018.

Hancher, Lee; Salerno, Francesco Maria (2017): 'EU energy and competition: analysis of current trends and a first assessment of the new package'. In Rafael Leal-Arcas, Jan Wouters (Eds.): Research handbook on EU energy law and policy. Cheltenham, UK: Edward Elgar Publishing (Research handbooks in European law), pp. 48-66.

Helm, Dieter (2012): 'European Energy Policy'. In Erik Jones, Anand Menon, Stephen Weatherill (Eds.): The Oxford handbook of the European Union. Oxford: Oxford University Press, pp. 556-68.

Helm, Dieter (2014): 'The European framework for energy and climate policies'. In Energy Policy 64, pp. 29-35.

Juncker, Jean-Claude (2014): Mission Letter. Vice President for Energy Union. Brussels. Available online at

https://ec.europa.eu/commission/commissioners/sites/cwt/files/commissioner_mission_letters/sefcovic _en.pdf, checked on 5/9/2018.

Keay, Malcolm (2016): 'Electricity markets are broken. Can they be fixed?' OIES paper, EL 17. Oxford Institute for Energy Studies.

Keay, Malcolm; Robinson, David (2017): 'The Decarbonised Electricity System of the Future: The 'Two Market' Approach'. Energy Insight, 14. Oxford Institute for Energy Studies. Available online at https://www.oxfordenergy.org/wpcms/wp-content/uploads/2017/06/The-Decarbonised-ElectricitySysytem-of-the-Future-The-Two-Market-Approach-OIES-Energy-Insight.pdf.

Kristov, Lorenzo; Martini, Paul de; Taft, Jeffrey D. (2016): 'A Tale of Two Visions: Designing a Decentralized Transactive Electric System'. In IEEE Power and Energy Magazine 14 (3), pp. 63-9. DOI: 10.1109/MPE.2016.2524964. 

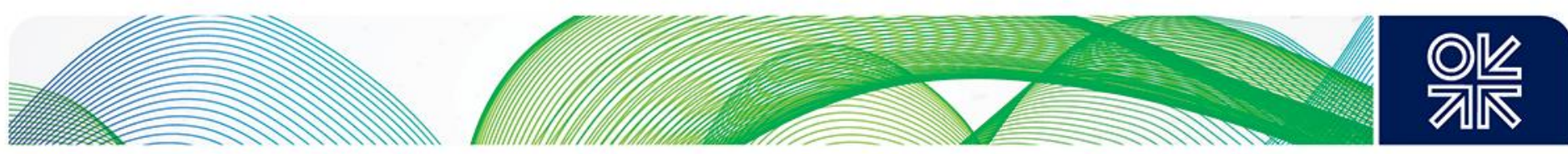

Labelle, Michael Carnegie (2017): 'Regulating for Consumers? The Agency for Cooperation of Energy Regulators'. In Svein S. Andersen, Andreas Goldthau, Nick Sitter (Eds.): Energy Union. Europe's new liberal mercantilism? London: Palgrave Macmillan (International political economy series), pp. 14764.

Maltby, Tomas (2013): 'European Union energy policy integration: A case of European Commission policy entrepreneurship and increasing supranationalism'. In Energy Policy 55, pp. 435-44.

Pellerin-Carlin, Thomas (2017): 'The European Energy Union'. In Rafael Leal-Arcas, Jan Wouters (Eds.): Research handbook on EU energy law and policy. Cheltenham, UK: Edward Elgar Publishing (Research handbooks in European law), pp. 67-102.

Peng, Donna; Poudineh, Rahmatallah (2017): 'Electricity market design for a decarbonised future. An integrated approach'. OIES paper, EL 26. Oxford Institute for Energy Studies.

Pierpont, Brendan; Nelson, David (2017): 'Markets for low carbon, low cost electricity systems'. CPI Working Paper. Available online at https://climatepolicyinitiative.org/wp-content/uploads/2017/10/CPIMarkets-for-low-carbon-low-cost-electricity-systems-October-2017.pdf, checked on 21/11/2018.

Schmidt, Susanne K. (1998): 'Commission activism: subsuming telecommunications and electricity under European competition law'. In Journal of European Public Policy 5 (1), pp. 169-84.

Schubert, Samuel R.; Pollak, Johannes; Kreutler, Maren (2016): Energy policy of the European Union. Basingstoke, Hampshire: Palgrave Macmillan (The European Union series).

Talus, Kim; Aalto, Pami (2017): 'Competences in EU energy policy'. In Rafael Leal-Arcas, Jan Wouters (Eds.): Research handbook on EU energy law and policy. Cheltenham, UK: Edward Elgar Publishing (Research handbooks in European law), pp. 15-29.

Thaler, Philipp (2016): 'The European Commission and the European Council: Coordinated Agenda setting in European energy policy'. In Journal of European Integration 38 (5), pp. 571-85. DOI: 10.1080/07036337.2016.1178252.

UCTE (2007): 'Final Report - System Disturbance on 4 November 2006'. Brussels. Available online at https://www.entsoe.eu/fileadmin/user_upload/_library/publications/ce/otherreports/Final-Report20070130.pdf.

van der Heijden, Kees (2005): Scenarios - The art of strategic conversation. 2nd ed. Chichester: Wiley.

van Hulten, Michiel; Sitter, Nick (2017): 'Something for Everyone: Political Fragmentation and Policy Accommodation in the European Parliament'. In Svein S. Andersen, Andreas Goldthau, Nick Sitter (Eds.): Energy Union. Europe's new liberal mercantilism? London: Palgrave Macmillan (International political economy series), pp. 223-36.

Vinois, Jean-Arnold (2017): 'The Road to Energy Union'. In Svein S. Andersen, Andreas Goldthau, Nick Sitter (Eds.): Energy Union. Europe's new liberal mercantilism? London: Palgrave Macmillan (International political economy series), pp. 27-50. 